\title{
Supergene Copper and the Ancient Mining Landscapes of the Atacama Desert: Refining the Protocol for the Study of Archaeological Copper Minerals through the Case Study of Pukara de Turi
}

Pía Sapiains ${ }^{1, *(\mathbb{D})}$, Valentina Figueroa ${ }^{2}$, Frances Hayashida ${ }^{3}$, Diego Salazar ${ }^{4}$, Andrew Menzies ${ }^{5}$, Cristián González ${ }^{6}$, Rodrigo Loyola ${ }^{7}$, Beau Murphy ${ }^{3}$, Juan González ${ }^{8} \mathbb{D}$, César Parcero-Oubiña ${ }^{9} \mathbb{D}$ and Andrés Troncoso 4 (D)

Citation: Sapiains, P.; Figueroa, V.; Hayashida, F.; Salazar, D.; Menzies, A.; González, C.; Loyola, R.; Murphy,

B.; González, J.; Parcero-Oubiña, C.; et al. Supergene Copper and the Ancient Mining Landscapes of the Atacama Desert: Refining the Protocol for the Study of Archaeological Copper Minerals through the Case Study of Pukara de Turi. Minerals 2021, 11, 1402. https://doi.org/10.3390/ $\min 11121402$

Academic Editors: Daniel

Albero Santacreu, José

Cristóbal Carvajal López and Adrián Durán Benito

Received: 6 November 2021 Accepted: 8 December 2021 Published: 11 December 2021

Publisher's Note: MDPI stays neutral with regard to jurisdictional claims in published maps and institutional affiliations.

Copyright: (c) 2021 by the authors. Licensee MDPI, Basel, Switzerland. This article is an open access article distributed under the terms and conditions of the Creative Commons Attribution (CC BY) license (https:/ / creativecommons.org/licenses/by/ $4.0 /)$.
1 Doctorado en Ciencias Mención Geología, Departamento de Ciencias Geológicas, Universidad Católica del Norte, Antofagasta 1240000, Chile

2 Instituto de Investigaciones Arqueológicas y Museo (IIAM), Universidad Católica del Norte, San Pedro de Atacama 1410000, Chile; vfigueroa@ucn.cl

3 Department of Anthropology, University of New Mexico, Albuquerque, NM 87131, USA; fmh@unm.edu (F.H.); bgm10@unm.edu (B.M.)

4 Departamento de Antropología, Universidad de Chile, Santiago 7800284, Chile; dsalazar@uchile.cl (D.S.); atroncos@uchile.cl (A.T.)

$5 \quad$ Bruker Nano GmbH, 12489 Berlin, Germany; andrew.menzies@bruker.com

6 MPhil/Ph.D. Programme, Institute of Archaeology, University College London, 31-34 Gordon Square, London WC1H 0PY, UK; c.gonzalez-rodriguez@ucl.ac.uk

7 Instituto de Investigaciones Arqueológicas y Museo (IIAM), Universidad Católica del Norte-UMR 7055 Prehistoire et Technologie (PreTéch), Université Paris Ouest Nanterre La Défense, 92000 Nanterre, France; rodarkeo@gmail.com

8 Department of Civil Engineering, Universidad Católica de la Santísima Concepción, Concepción 4090541, Chile; jgonzal@ucsc.cl

9 Instituto de Ciencias del Patrimonio (Incipit), Consejo Superior de Investigaciones Científicas (CSIC), 15705 Santiago de Compostela, Spain; cesar.parcero-oubina@incipit.csic.es

* Correspondence: psg004@ucn.cl

\begin{abstract}
Northern Chile is home to the world's largest copper ore deposits, which have been exploited for thousands of years by different groups, at varying scales and for different purposes. In this context, it is important to develop new protocols to characterise the mineralogical variability of archaeological copper ores. A comprehensive and representative methodology in the analysis of minerals, the application of non-destructive analytical techniques, and the combination of insights from geological, archaeological and local knowledge are key to developing a copper mineral repository of the Atacama Desert area. Geochemical analyses were applied to the study of 568 samples from the archaeological site Pukara de Turi, with different techniques such as micro-XRF, XRD, QEMSCAN, Raman spectroscopy and technological studies. This exhaustive analysis allowed for the recognition of two mineralogical associations: atacamite/brochantite (99\%) and azurite/chrysocolla (1\%). The study of various minerals allows data to be interpreted more reliably and to trace the likely geological sources of these minerals. The azurite/chrysocolla samples appear to belong to the same mineral association found in the Cerro Verde district, which is probably the source of these samples. The atacamite/brochantite samples appear to come from more than one geological source, including, but not limited to, Chuquicamata-Radomiro Tomic and El Abra-Conchi.
\end{abstract}

Keywords: copper minerals; micro-XRF; archaeometry

\section{Introduction}

The Atacama Desert is home to the world's largest copper deposits, which have been exploited for thousands of years by different groups, at varying scales and for dif- 
ferent purposes (Figure 1). Since pre-Hispanic times, a mining economy in the Atacama Desert supplied regional and interregional demand for copper ore uses such as metallurgy, lapidary, pigmentary and ores (in the form of powder, nodules and fragments).

Copper mining has a deep-rooted history dating back to the Formative Period (ca. 1500 BC-400 AD) to the Inca Horizon (ca. 1400-1540 AD) [2-4]. Mining districts in the Atacama Desert were exploited by the Incas from the mid-15th century, who kept their technology and reorganised mining activity [5-9]. However, these activities almost entirely ceased after the Hispanic Conquest and the installation of the colonial system. Nonetheless, the production and use of copper continued during colonial times, the Republican Period and is even carried out today by local indigenous communities [10]. Unlike in other regions of the South-Central Andean Area, where complex metallurgical industries developed [11,12], on the western side of the Circumpuna, metallurgy was a secondary activity during prehistory $[13,14]$. The bulk of mining production was destined for lapidary uses and, particularly, to supply the needs of local ritual ceremonies, in which copper ores played a prominent role as offerings. In the Andean world, the geological and mineral landscape was not part of an inert mineral world-since time immemorial, Andean peoples have personified the landscape, considering it alive. Copper minerals were offered in various contexts, identified in a range of settings: residential, agricultural (terraces, water holes, springs and wells), rock art (in paintings or offerings to them), funerary (nodules, beads, powders, pigments), monumental (tumuli), in paraphernalia (tablet and inhalation tube inlays, mortars, pylons and spoons), on top of certain hills, on ceremonial tables (walls and boxes) and in passageways, openings and routes (e.g., [15-22]). Given this variety of uses, copper minerals are among the most ubiquitous remains to be found in archaeological sites throughout the Atacama Desert.

The abundance of mineral sources in the area has also led to deep levels of local knowledge and expertise in the fields of mineralogy and geochemistry [23-25] among others; therefore, the Atacama Desert is a privileged place to research copper ores and their uses over long timescales of human civilisation. Since the variability and complexity of copper deposits in the area make them challenging to characterise, many researchers have developed different mineral study methodologies based on this zone [26-29], among others. In addition, there is an extensive body of archaeological literature on the problems of copper mineral source characterisation and the limitations of such approaches.

In this study, samples were collected from the Pukara de Turi, an extensive 4 ha archaeological site from the Late Intermediate and Inca Periods (ca. 11th-16th centuries), located in northern Chile (Figure 2). We analysed 568 samples with geochemical analyses using micro-X-ray fluorescence $(\mu-X R F)$. In addition, the following analyses were performed: $X$ ray diffraction (XRD), Raman spectroscopy and QEMSCAN, which allowed us to improve the understanding of pre-Hispanic copper ore technologies in the Atacama Desert in the context of mineral raw materials, as well as knowing how they were used in archaeological times through the recognition of mineral paragenesis. In addition, we carried out a technological study of the mineral assemblages. This was intended to characterise the diversity of copper ores from the Pukara de Turi and its diverse uses within the site. The analyses detailed in Sections 4.1-4.4 were carried out at Unidad de Equipamiento Científico-MAINI, at Universidad Católica del Norte, Antofagasta, Chile. 


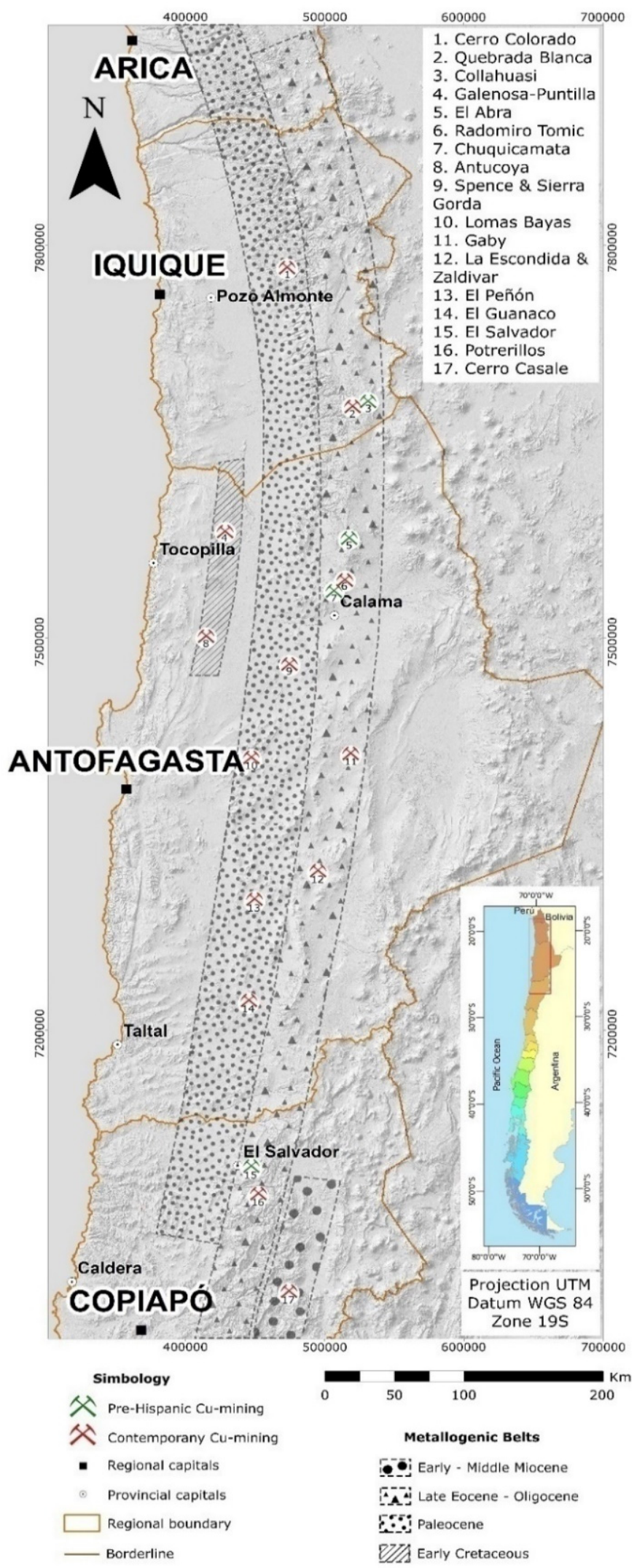

Figure 1. Metallogenic belts in northern Chile, mining districts and copper mines. Metallogenic belts were modified from [1]. 


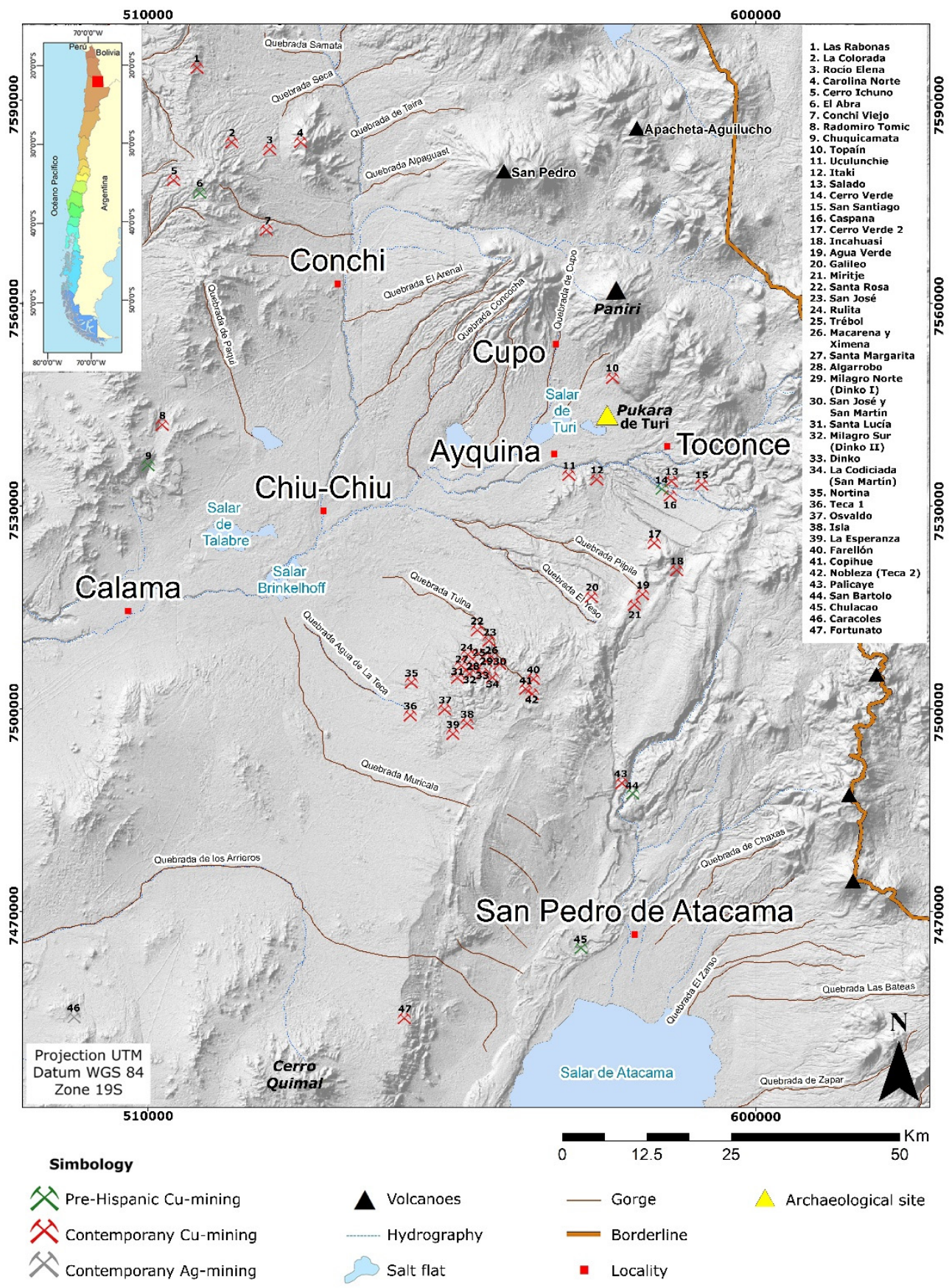

Figure 2. Location map, showing the copper and silver deposits in the area. Pre-Hispanic copper mines are highlighted with a green symbol and modern copper mines with a red symbol.

\section{Geochemical Characterisation of Pre-Hispanic Copper Ores in the Atacama Desert}

The regional extent and distribution of the mining landscapes of the Atacama Desert can be characterised by considering the distances between populated nodes, based on water availability from rivers and oases, and mining districts [9], whose location is controlled by the underlying geology. Over the course of prehistoric times, Atacama societies developed an understanding of regional geography based on the needs of their social, technological and ritual systems that required access to mining districts to extract minerals and then redistribute them in their various contexts of use. To understand these mining landscapes, studies must, therefore, take into consideration the location and characteristics of mining districts and their relation to the areas where minerals were used. 
The Pukara de Turi archaeological study sites lie within the Upper Eocene-Oligocene metallogenic belt (43-31 Ma) defined by [1,25,30], among others (Figure 1), where several pre-Hispanic mines have been identified and studied $[6,7,9,14,31-38]$. Copper deposits have a geochemical signature that is strongly dependent on the geological context of their formation [39]. Supergene ores form from the reaction of hydrothermally derived ores with near-surface meteoric water. The paragenesis of copper oxide minerals reveals that a specific series of progressive mineralogical changes take place during supergene oxidation, transport and precipitation [40]. Thus, to determine the sources of copper, it is important to define the paragenesis of minerals from pre-Hispanic mining districts and their impurities, which can be expressed as minor elements (comprising $0.1-1 \%$ of the rock mass) or as trace elements $(<0.1 \%)$. These signatures are unique to each deposit and thus correspond to markers of the sample's geochemical origin [39]. Oxidised copper minerals may also have visible variations in their macroscopic characteristics which indicate the heterogeneity of their mineralisation [41]. In summary, the detailed study of trace element geochemistry allows each mineral type to be characterised in copper ore samples, thus delimiting their probable origin [42].

In the past 10 years, several analytical techniques have been used to characterise a range of mineral samples from archaeological sites in northern Chile. These include techniques such as X-ray diffraction (XRD) [43,44], X-ray fluorescence (XRF) [43,45], ParticleInduced X-Ray Emission (PIXE) [46,47], Scanning Electron Microscopy with Energy Dispersive Spectrometers (SEM-EDS) [48,49], Raman Spectroscopy [20] and automated mineralogical analysis (QEMSCAN) [6,28]. Copper ores primarily exploited by pre-Hispanic miners correspond to those found in the oxidised zone (i.e., antlerite $\left(\mathrm{Cu}_{3} \mathrm{SO}_{4}(\mathrm{OH})_{4}\right)$, atacamite $\left(\mathrm{Cu}_{2} \mathrm{Cl}(\mathrm{OH})_{3}\right)$, brochantite $\left(\mathrm{Cu}_{4} \mathrm{SO}_{4}(\mathrm{OH})_{6}\right)$, chrysocolla $\left(\left(\mathrm{Cu}, \mathrm{Al}_{2}\right)_{2} \mathrm{H}_{2} \mathrm{Si}_{2} \mathrm{O}_{5}(\mathrm{OH}) \cdot \mathrm{nH} 2 \mathrm{O}\right)$, pseudomalachite $\left(\mathrm{Cu}_{5}\left(\mathrm{PO}_{4}\right)_{2}(\mathrm{OH})_{4}\right)$ and turquoise $\left(\mathrm{CuAl}_{6}\left(\mathrm{PO}_{4}\right)_{4}(\mathrm{OH})_{8} \cdot 4 \mathrm{H}_{2} \mathrm{O}\right)$, among others), which precipitate close to the surface [40] and whose exploitation was possible with pre-Hispanic mining technology [2].

On the basis of these previous studies, we attempted to gain new insights into the geochemical characterisation of pre-Hispanic copper ores. In particular, although several analytical techniques have recently been used to characterise mineral samples from archaeological contexts in northern Chile with increasing precision, we suggested that the study of archaeological copper minerals requires an integrated approach, taking into account other variables (e.g., ore deposition, distribution, gravity, gangue, technology, rituality, etc.). Such an approach is crucial to develop a broader understanding of copper production in this context, such as contemporary technology, mobility and exchange.

\section{Selection and Description of Samples}

Turi was a residential and administrative centre, occupied in the Late Intermediate Period (LIP) (ca. 1000-1400 AD) through the Inca (ca. 1400-1540 AD) period and early colonial times (16th and with a small 17th century occupation [50]). Pukara de Turi has many copper ore concentrations (mineral concentrations) both inside and outside the site. The enclosures studied correspond to both the LIP and Inca occupation of the site.

Some of the concentrations correspond to stocks of copper mineral offerings. In this work, MC2, MC3, MC5 and MC21 (Figure 3a) were excavated and studied (Figure 4). Our proposed methodology starts from the excavation itself since the selection of samples will affect the subsequent results. In this study, each excavation unit measured $50 \times 50 \mathrm{~cm}$ and was excavated following natural strata. Strata exceeding $5 \mathrm{~cm}$ of thickness were divided into arbitrary $5 \mathrm{~cm}$ levels. Sediments were passed through a $1 / 8^{\prime \prime}$ screen and minerals and other cultural material was recovered. Minerals from each concentration were then labelled, and the total bulk material collected was then separated into samples, each comprising $1 / 8$ by weight of each level by units, which were sent to the geochemistry laboratory (Table 1). The samples from the excavation were observed using a geological magnifying glass $(14 \times$ magnification) to identify fragments that showed copper mineralisation, including partially or fully mineralised rock fragments (Figure 3b). 
The samples were small angular fragments of copper ore between 3 and $5 \mathrm{~mm}$ in length. The fragments can be described as (i) small fragments of pure minerals, (ii) quartz fragments that are green in appearance due to traces of copper mineralisation and (iii) minerals with little gangue. In some fragments, the mineralisation appears as a patina on the rock and with intergrowth textures.

For the analytical techniques mentioned above, the archaeological samples did not need to be specifically prepared. Using this approach, 568 mineral fragments were selected and analysed via $\mu$-XRF (Figure 4). To confirm the mineralogy, we used XRD to analyse four of the samples previously examined with $\mu$-XRF. The use of XRD is a destructive approach as it was necessary to pulverise the mineral fragments. In addition, we applied automated mineralogy (QEMSCAN) to seven mineral fragments from the MC samples of Pukara de Turi, and, in addition, to four mineral fragments relatively close to the possible geological sources from the AB-20, Chu-2 and Chu-4 mining sites [7] (located close to El Abra-Conchi and Chuquicamata-Radomiro Tomic mining districts, respectively (see Figure 2, mines mentioned are identified with symbology of the mining districts and numbers 6-9 on the map). Additionally, we analysed a sample from a vein composed of quartz and feldspar with copper mineralisation. The vein fragment was a core (a mass of raw material fractured to obtain flakes or blanks through knapping) and was found in a typical building of the Inca architecture called a Compound Perimeter Enclosure (also known by the Spanish acronym RPC (Recinto Perimetral Compuesto)) (Figure 3d).

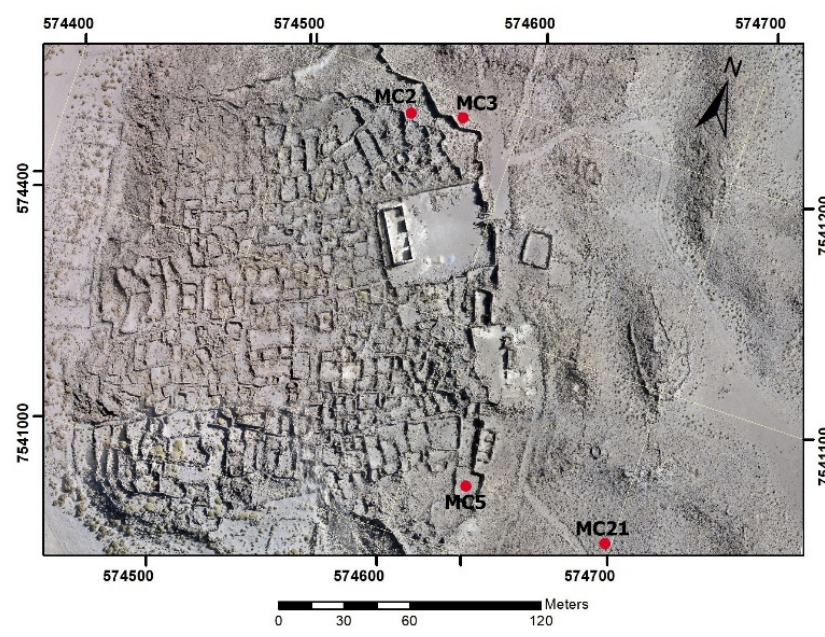

(a)

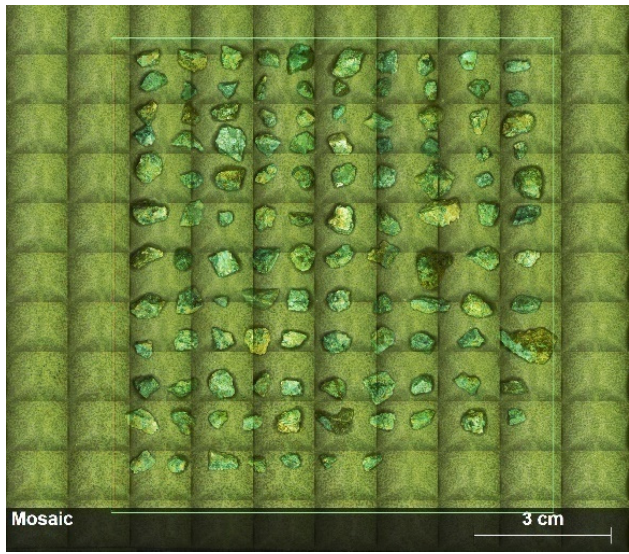

(c)

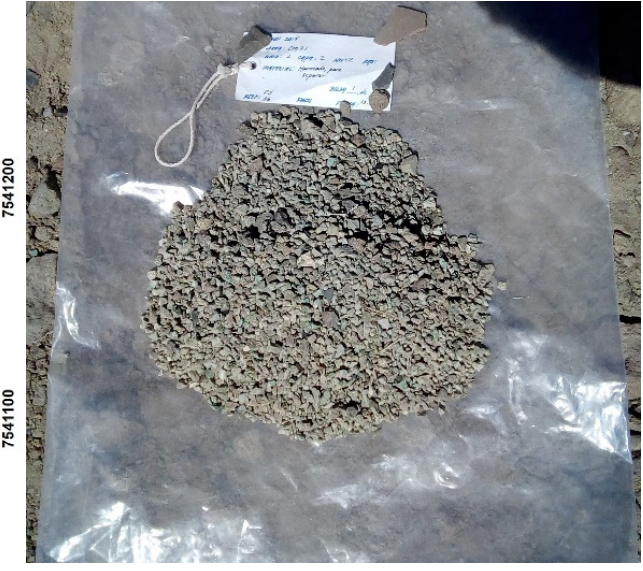

(b)

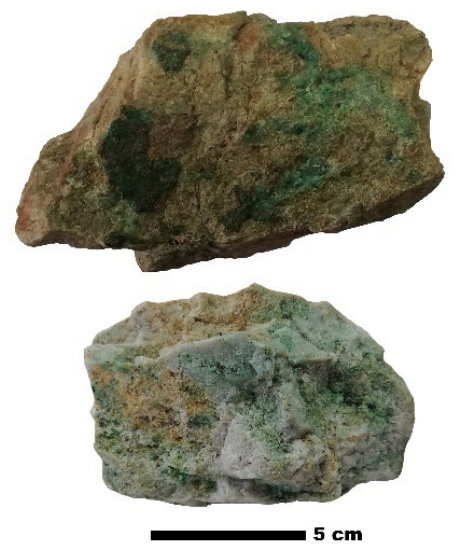

(d)

Figure 3. (a) Location of the samples in the place where mineral concentration (MC) was excavated on the site. (b) Sediments and minerals collected in the grid. (c) Samples selected for analytical analysis in $\mu$-XRF from MC21 (layer 2, level 3). (d) Core sample collected in Inca building (RPC); the two sides of the sample can be seen, one weathered and the other a fresh side. 

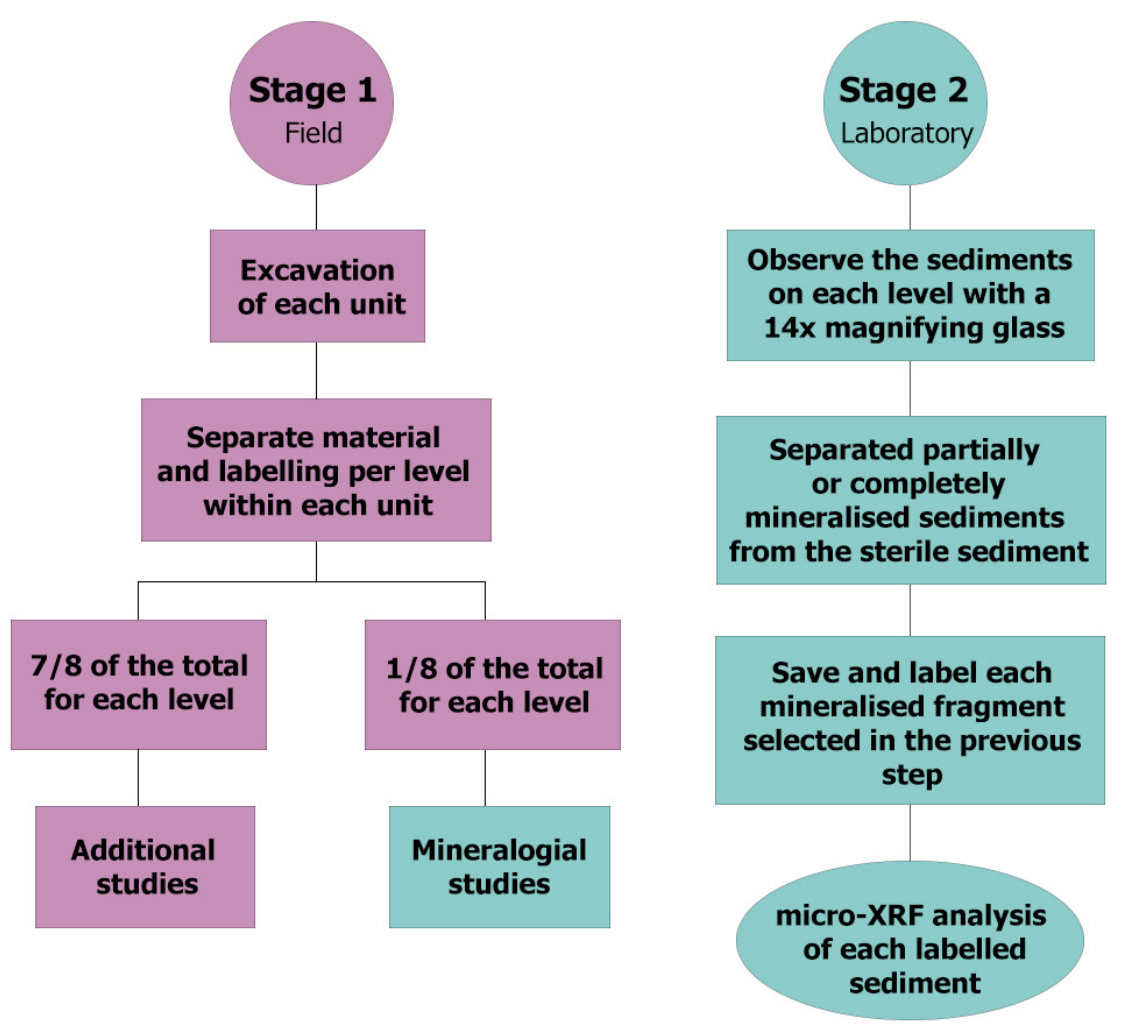

Figure 4. Outline of the analytical protocol.

Table 1. Excavated units (MC2, MC3, MC5 and MC21) by layer and level. In the code, U means a unit, $\mathrm{C}$ means layer and $\mathrm{N}$ means level.

\begin{tabular}{cccc}
\hline Unit & Code & Weight $\mathbf{( 1 / 8}$ Total Weight) & Samples Analysed \\
\hline \multirow{5}{*}{ MC2 } & U1C1N1 & $35.29 \mathrm{~g}$ & 21 \\
& U1C2N1 & $19.31 \mathrm{~g}$ & 14 \\
& U1C2N2 & $41.35 \mathrm{~g}$ & 36 \\
& U1C2N3 & $56.13 \mathrm{~g}$ & 26 \\
& U1C2N4 & $27.64 \mathrm{~g}$ & 12 \\
U1C2N5 & $42.52 \mathrm{~g}$ & 50 \\
\hline \multirow{3}{*}{ MC3 } & U1C1N1 & $18.74 \mathrm{~g}$ & 6 \\
& U1C2N1 & $24.14 \mathrm{~g}$ & 21 \\
& U1C3N1 & $6.43 \mathrm{~g}$ & 5 \\
\hline \multirow{5}{*}{ MC5 } & U1C1N1 & $107.24 \mathrm{~g}$ & 50 \\
& U1C2N1 & $47.86 \mathrm{~g}$ & 26 \\
& U1C3N1 & $77.65 \mathrm{~g}$ & 40 \\
& U1C3N2 & $32.45 \mathrm{~g}$ & 25 \\
& U1C3N2-rasgo & $11.28 \mathrm{~g}$ & 9 \\
& U1C3N3 & $100.34 \mathrm{~g}$ & 31 \\
\hline \multirow{3}{*}{ MC21 } & U2C1N1 & $105.67 \mathrm{~g}$ & 48 \\
& U2C2N1 & $14.78 \mathrm{~g}$ & 11 \\
& U2C2N2 & $114.33 \mathrm{~g}$ & 120 \\
\hline
\end{tabular}

\section{Analytical Methodology}

4.1. Micro-X-ray Fluorescence ( $\mu$-XRF)

Automated mineralogy, mineral element maps and major trace element mineral chemistry were obtained using a Bruker M4 Tornado ${ }^{\text {AMICS }} \mu$-XRF (Berlin, Germany). All these techniques could be acquired during a single analysis, with post-processing 
conducted using the Bruker M4 and ESPRIT software. We selected the $\mu$-XRF analysis technique because this approach allows for the analysis of many samples, providing fast and detailed mineralogical information, and it is a non-destructive technique that does not require sample preparation. For high precision of elemental data, we carried out supplementary individual point analyses. Analytical conditions and times vary depending on the information required and the sample type, among other factors. The Bruker $\mu$-XRF allows the distribution of elements with $\mathrm{Z} \geq 11$ (i.e., $\mathrm{Na}$ and above) and trace elements (down to $20 \mu \mathrm{g} / \mathrm{g}$ ) to be characterised; due to its polycapillary optics, an X-ray spot size of less than $20 \mu \mathrm{m}$ can be achieved. To optimally utilise this spot size, the stage has a step size resolution of $4 \mu \mathrm{m}$ [51].

The $\mu$-XRF instrument was equipped with dual XFlash ${ }^{\circledR}$ energy-dispersive silicon drift detectors (SDD) with $60 \mathrm{~mm}^{2}$ active areas and Be windows with parallel signal processing (for maximum throughput). Standard instrument conditions for X-ray beam excitation of the $\mathrm{Rh}$ target tube are $50 \mathrm{kV}$ and $600 \mu \mathrm{A}$, without a primary filter. For the $60 \mathrm{~mm}^{2}$ setup, this resulted in total input count rates of $\sim 500 \mathrm{kcps}$ on heavier elements (such as copper) and $\sim 60 \mathrm{kcps}$ on lighter elements (such as silicon). The current was adjusted depending on sample type and detector setup or size; the tube current could commonly range from 100 to $600 \mu \mathrm{A}$. The measurement dwell time per pixel was approximately $50 \mathrm{~ms}$ and was based on the pulse throughput on silicates (ideally quartz) to obtain a minimum of 2000 counts per pixel for mineral identification. This requirement resulted in dwell times typically in the range of 20 to $50 \mathrm{~ms}$; for the throughput of the XSPV 130 spectroscopic amplifier (equivalent to $0.8 \mu \mathrm{s}$ shaping time), the intensity was approximately $50 \mathrm{kcps}$ for quartz and maintained a spectrometric energy resolution of $145 \mathrm{eV}$ at $\mathrm{Mn} \mathrm{K} \alpha$. The X-ray spot size was approximately $15 \mu \mathrm{m}$ and the samples were analysed using a variety of stepping intervals, e.g., 100, 50 or $20 \mu \mathrm{m}$. The source X-rays interacted with the sample at a fixed position, and analytical measurements were performed by moving the highly precise and rapid servo stage [51]. The analytical conditions applied in point analyses for the protocol were also used for the next measurements, namely a time of $60 \mathrm{~s}$ per point analysis, tube current of $200 \mu \mathrm{A}$, a polycapillary value of $50 \mathrm{kV}$ and total input count rates of $130 \mathrm{kcps}$.

\subsubsection{Mineral Classification Using $\mu$-XRF Data}

Each of the mineral definitions in the M4 TORNADOAMICS mineral list contains numerous sub-definitions for different specific minerals. For example, the $\mathrm{Cu}$-sulphides group contains definitions for chalcopyrite $\left(\mathrm{CuFeS}_{2}\right)$, bornite $\left(\mathrm{Cu}_{5} \mathrm{FeS}_{4}\right)$, chalcocite $\left(\mathrm{Cu}_{2} \mathrm{~S}\right)$, etc., each of which has a fixed composition and, thus, a relatively robust classification in the standard mineral library. In other cases, minerals or mineraloids must be added to the database due to their rarity, e.g., black-Cu and green-Cu ores [51], or due to variable compositions as a result of solid solution, e.g., silicates such olivine, pyroxenes, feldspars, etc. This classification is important if the $\mu$-XRF results are to be used to calculate elemental concentrations or behaviour. When examining spectra for trace elements, quantifying solid solutions or confirming stoichiometric minerals, the standardised parameter quantification in the M4 software provided precise results. However, for higher accuracy, the imperial or Polynomial methods were also used with a large pure element and mineral standard database acquired with the instrument.

\subsubsection{Elemental Maps and Point Analyses Using $\mu-X R F$}

To characterise the samples, an elemental map was made to gain a general overview of each sample's major and trace elements, and individual point analysis was used to refine the results. The samples were observed macroscopically and based on the macroscopic features of the minerals, we selected the point upon which to conduct the analysis. The point analyses were made on the predominant mineral in each sample. This decision does not exclude the fact that some samples contained a mixed association of minerals; however, if a sample visually contained $>50 \%$ of a particular mineral phase, the point analysis was conducted on this mineral and the sample was classified as this mineral type. 


\subsection{X-ray Diffraction (XRD)}

$\mathrm{XRD}$ is an analytical technique that allows the crystalline phases of a solid to be determined by bombarding the sample with an X-ray beam at varying angles [52]. To determine the mineralogy of a sample, the sample must first be pulverised and then placed in a briquette. In our analytical protocol, this technique was used in addition to $\mu$-XRF to confirm the mineralogy of the samples. Samples were prepared in the Applied Geochemistry Laboratory, Geological Sciences Department, Universidad Católica del Norte, Chile. The analytical conditions are presented in Table 2.

Table 2. The operating conditions of an automatic and computerised X-ray Diffractometer, Bruker brand, Model D8 Advance, are presented.

\begin{tabular}{cc}
\hline Analytical Parameter & Selection \\
\hline Goniometer & Vertical Bragg-Brentano \\
Radiation & Cu Ka1 (I =1.5406 ̊) \\
Voltage & $40 \mathrm{kv}$ \\
Intensity & $30 \mathrm{~mA}$ \\
Detector & Scintillation counter \\
Secondary monochromator & Not applicable \\
Slits & $1 \mathrm{~mm} / 1 \mathrm{~mm} / 0.2 \mathrm{~mm}$ \\
Scan range & $3-70^{\circ} 2 \theta$ \\
Step size & $0.020^{\circ} 2 \theta$ \\
Step time & $1.10 \mathrm{~s}$ \\
Data base & ICDD (International Centre for Diffraction Data) \\
Quantification program & TOPAS (Total Pattern Analysis Software) \\
\hline
\end{tabular}

\subsection{Raman Spectroscopy}

Raman spectroscopy is based on the interaction of light from a laser with chemical bonds in a sample. Raman spectra are unique to each chemical composition and provide qualitative and quantitative information about a material. The Raman spectra of minerals are very well defined, as they have a specific crystalline structure. These spectra can be found in freely accessible databases. Like $\mu$-XRF, this technique is advantageous in that it is non-destructive, which is particularly important in some archaeological contexts. In our protocol, we applied Raman spectroscopy to confirm the mineralogy of the anomalous samples, which corresponded to 5 out of 568 (i.e., $<1 \%$ of the total number of samples analysed); this non-destructive approach was favoured as the preservation of these archaeological samples is essential for future studies. The samples were analysed using the He-Ne 633 nm laser.

\subsection{Automated Mineralogy (QEMSCAN)}

QEMSCAN $^{\circledR}$ (Quantitative Evaluation of Materials by Scanning Electron Microscopy) analysis measures the mineralogical variability of a sample based on its micrometrescale geochemistry. The analytical results obtained through the automated mineralogy approach are received and analysed in the form of spectra signals, where each mineral has a specific spectrum according to its chemical composition. This technique provides information relating to mineralogy, mineral textures and the relative content of chemical elements through mineralogical maps [28]. Each sample was mounted in a $30 \mathrm{~mm}$ circular epoxy resin briquette; the briquettes were then cured, polished and carbon-coated prior to conducting the automated mineralogical analysis. The equipment was used in Field Scan mode [28] with the following parameters: field size $2500 \mu \mathrm{m}$, point spacing $5.0 \mu \mathrm{m}$ and 500 points across the field.

\subsection{Technological Study}

To understand the diversity of minerals in the social context of their production, we also carried out a technological study regarding the Turi assemblages, adapting the 
methodologies that are typically used for lithic industries [53]. The study was aimed at understanding the manufacturing techniques and chaine opératorie [53] of the final products. In the first stage, the assemblages were separated according to the variability of their minerals; subsequently, they were classified into general technological categories (cores, blanks, gangue-waste and final products), and the pieces were then measured and weighed. By comparing archaeological artifacts with the results of our experimental analyses, the production techniques were identified, and the different stages of the operational chains were reconstructed.

In order to identify the reduction technique, we carried out experimental tests on minerals. These tests were aimed at distinguishing the use of grinding (used in metallurgical industries and "challa" offerings of minerals) from knapping techniques, generally used in lapidary industries. As raw materials, chrysocolla, atacamite, turquoise and green onyx from local sources were employed. The following techniques were performed on these minerals: (1) hard mineral percussion (stone hammer); (2) hard mineral percussion supported on an anvil (bipolar percussion or split fracture); (3) organic soft tangential percussion with a wooden hammer (carob or algarrobo); and (4) pressure with a bone compressor (vicuña metapodium) [54,55]. A pumice pebble was used for platform preparation. In addition, we ground the minerals on a basalt stone anvil, using a hand-prepared granite grinding approach to reduce the mineral to fragments of $5 \mathrm{~mm}$ diameter.

Through a comparison of the technical stigmas (impact point, percussion cone, bulb, waves, lancets and lip) of the debris and negatives based on both experimental references and the archaeological samples, the different reduction techniques were recognised. In addition, taphonomic processes such as macroscopic fractures and abrasion were evaluated using a microscope.

\section{Results}

\subsection{Mineralogy of Samples with Micro-X-ray Fluorescence, X-ray Diffraction and} Raman Spectroscopy

The predominant mineralogy corresponds to an association between atacamite $\left(\mathrm{Cu}_{2} \mathrm{Cl}(\mathrm{OH})_{3}\right)$ and brochantite $\left(\mathrm{Cu}_{4} \mathrm{SO}_{4}(\mathrm{OH})_{6}\right)$, dominated by atacamite (Figure 5).

In addition, some samples were classified as gangue (188 out of 568; i.e., quartz and feldspars with copper mineralisation or dyed blue or green). These samples were analysed to understand the source of the copper ores more precisely and thoroughly. In the point analysis of samples classified as atacamite, two peaks in the spectrum were clearly observed, i.e., $\mathrm{Cl}$ and $\mathrm{Cu}$ (Figure $6 \mathrm{~b}$ ). These samples are not characterised by any distinctive trace elements. For the samples classified as brochantite, two peaks were observed in the spectrum, corresponding to $\mathrm{S}$ and $\mathrm{Cu}$ (Figure $\mathrm{7b}$ ).

The mineralogy of both minerals was confirmed with XRD (Figures 6a and 7a). The mineral gangue is almost exclusively composed of quartz; the corresponding point analyses indicated that quartz contains $\mathrm{Sr}$ and $\mathrm{Zn}$ as trace elements. In all excavated units (i.e., MC2, MC3, MC5 and MC21), the mineralised samples represent the highest percentage of the analysed samples. Layer 2 contains the highest proportion of copper ore samples ( $>60 \%$ of the total samples). In all units, the layers are numbered with increasing depth, with layer 1 being the shallowest and 3 being the deepest.

In unit MC2, there are two natural layers, from which a total of 159 samples were analysed. In layer 1 (superficial), a total of 21 samples were analysed, of which eight samples were classified as atacamite and six as brochantite; the remaining seven samples correspond to gangue minerals. In layer 2, a total of 138 samples were analysed, of which 78 were classified as atacamite, 21 were classified as brochantite and 39 samples were gangue minerals (Figure 8a). 


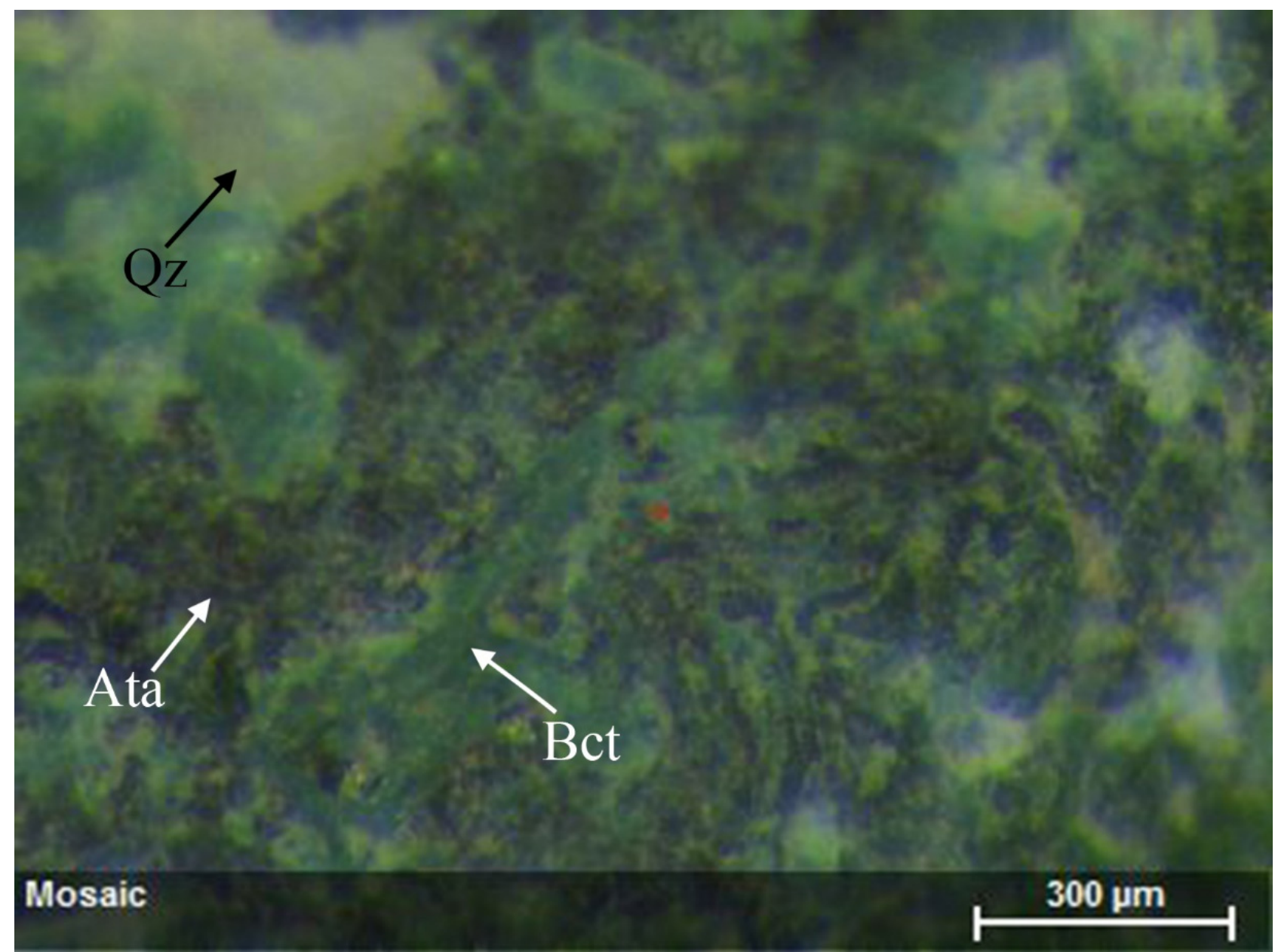

Figure 5. Atacamite/brochantite association common in the samples. Atacamite is the dominant copper mineral. Dark green is atacamite and light green is brochantite. Code sampleTu_U1C1N1_x11 from mineral concentration MC2, layer 1, level 1. Abbreviations: Qz: quartz, Ata: atacamite, Bct: brochantite.

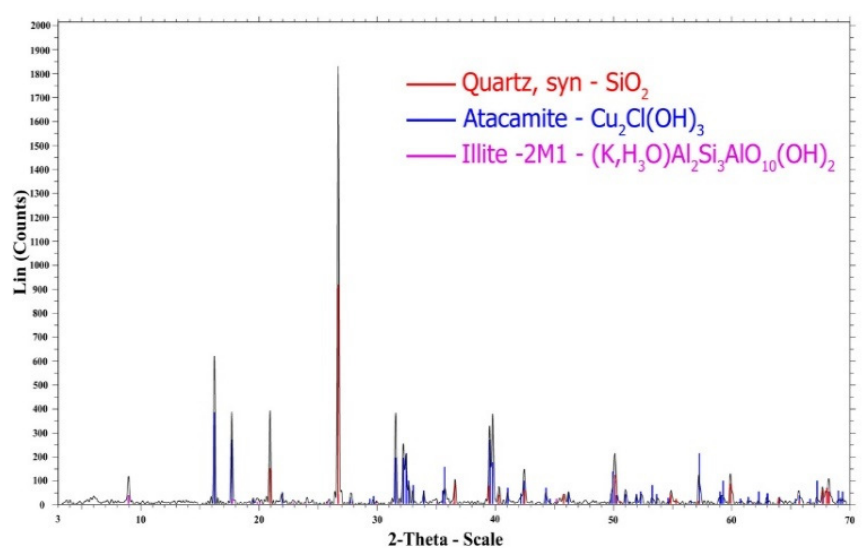

(a)

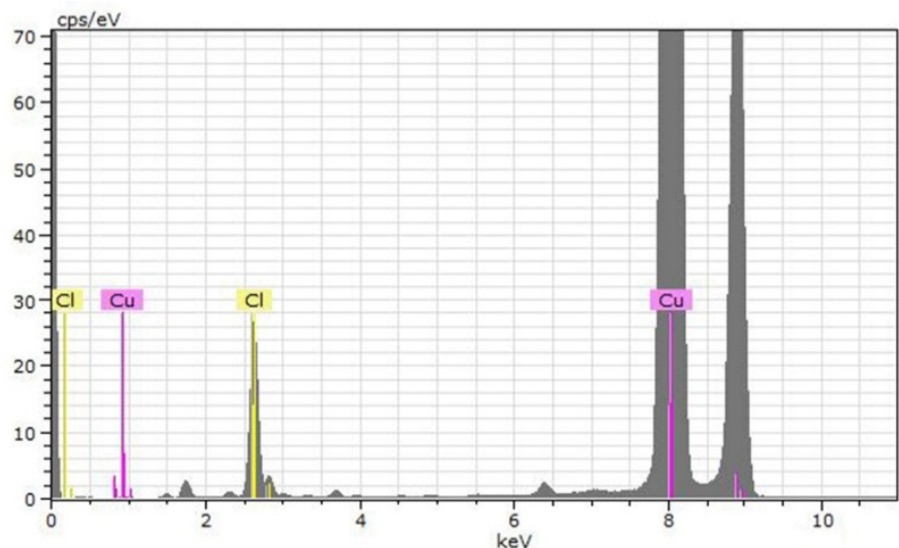

(b)

Figure 6. Atacamite sample, code Turi_U2_C2_N3_m10 from mineral concentration unit MC21, layer 2, level 3. (a) XRD spectrum of atacamite. (b) $\mu$-XRF spectrum of $\mathrm{Cl}$ and $\mathrm{Cu}$. 


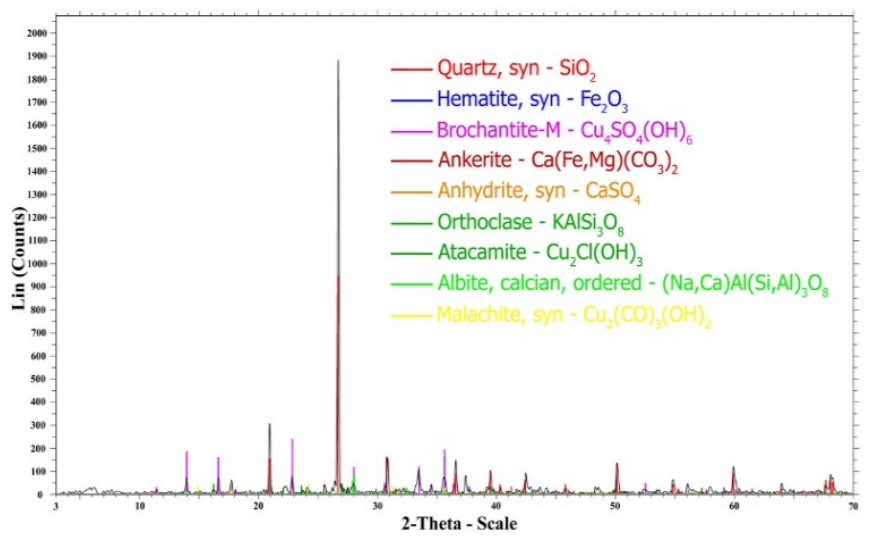

(a)

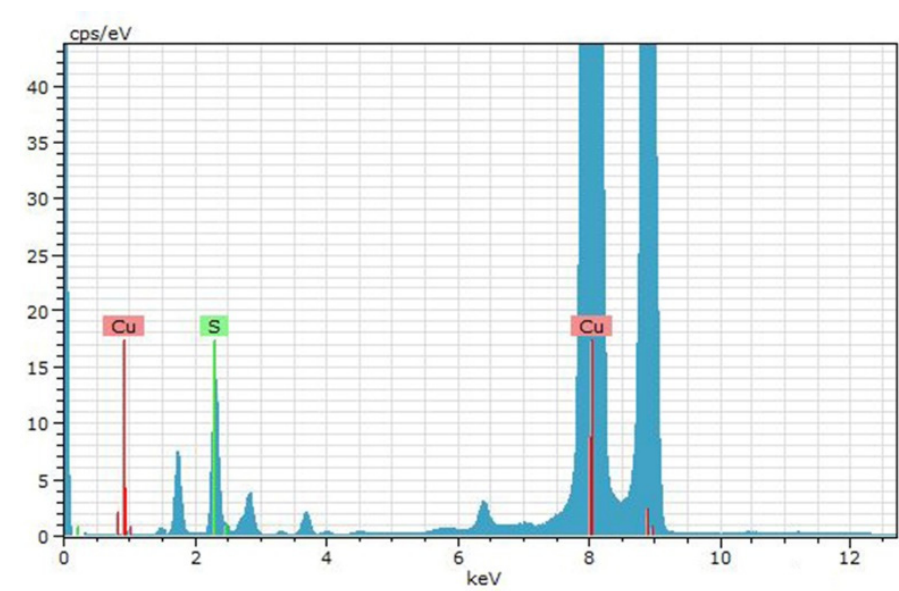

(b)

Figure 7. Brochantite sample, code Turi_U2_N3_m76 from mineral concentration unit MC21, layer 2, level 3. (a) XRD spectrum of brochantite. (b) $\mu$-XRF spectrum of $\mathrm{S}$ and $\mathrm{Cu}$.

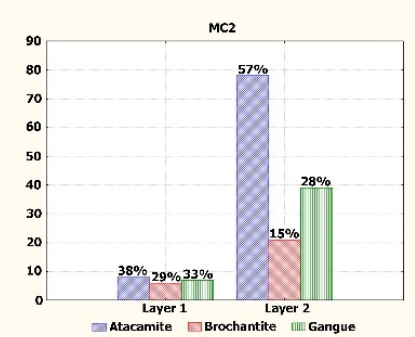

(a)

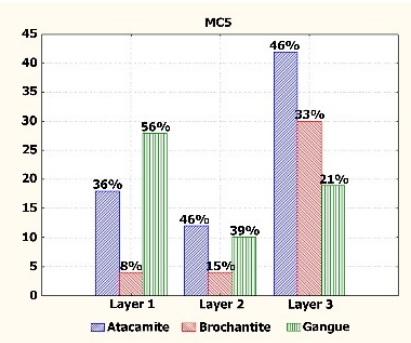

(c)
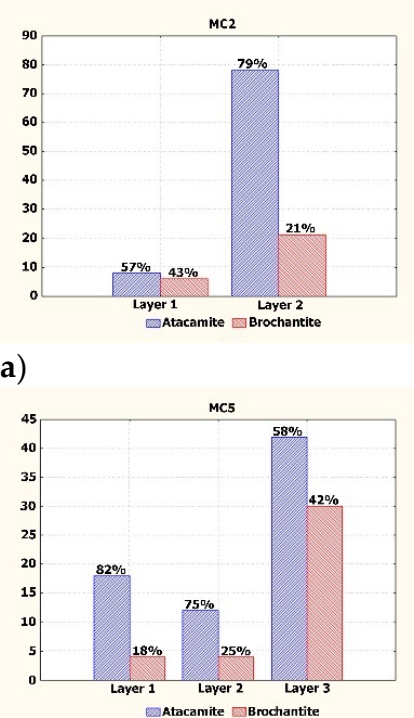
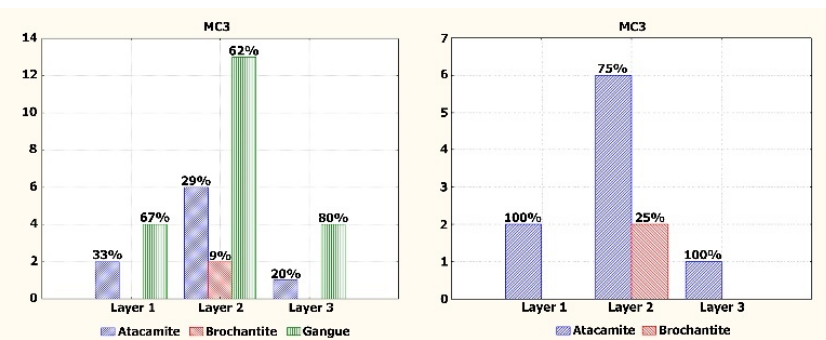

(b)
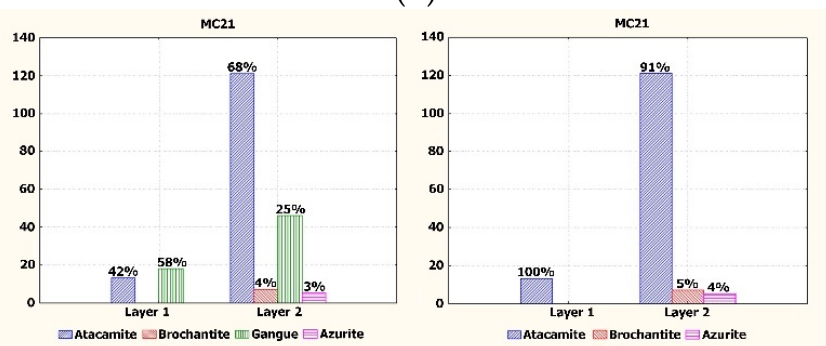

(d)

Figure 8. Abundance of minerals in each mineral concentration. (a) Unit MC2. On the left: percentages of mineralogical results including gangue are shown. In layer 1 and layer 2, atacamite predominates over brochantite and gangue. On the right: the percentages of minerals excluding gangue are shown. In layer 1, the percentage of samples classified as atacamite and brochantite is similar. On the other hand, in layer 2, there is a significant presence of atacamite over brochantite. (b) Unit MC3. On the left: layers 1, 2 and 3 show a predominance of sediments classified as gangue, i.e., quartz stained blue or with very little mineralisation in the form of patina. On the right, excluding the gangue, there is a predominance of atacamite in all the layers of the unit. (c) Unit MC5. On the left: layer 1 shows a predominance of gangue over mineralised samples. In layers 2 and 3, the percentage of gangue decreases, and the predominant mineralisation is atacamite. On the right: excluding gangue, the predominance of atacamite over brochantite is observed in all the layers of the unit. (d) Unit MC21. Right: in layer 1, gangue is more abundant than atacamite. In layer 2, there is a predominance of atacamite over gangue and, in addition, samples of azurite/chrysocolla were found, representing 3\% of the total samples analysed from the layer. On the right: the graphs excluding gangue show that in both layers, atacamite is the predominant mineral. The representation of azurite/chrysocolla mineralisation is very low with respect to atacamite/brochantite and is therefore considered anomalous.

The MC3 unit contains three layers in which a total of 32 samples were analysed. In layer 1 (surface level), a total of six samples were analysed, of which two samples were 
classified as atacamite and the rest were gangue minerals. In layer 2, a total of 21 samples were analysed, six of which were classified as atacamite, two as brochantite and thirteen samples were gangue minerals. In layer 3, a total of five samples were analysed, one of which was classified as atacamite, and the other four samples were gangue minerals (Figure 8b).

The MC5 unit comprises three layers, with a total of 167 samples analysed. In layer 1 (surface level), a total of 50 samples were analysed, of which 18 samples were classified as atacamite and 4 as brochantite; the remaining 28 samples were gangue minerals. In layer 2, a total of 26 samples were analysed, of which 12 were classified as atacamite, 4 as brochantite and 10 as gangue minerals. In layer 3, 91 samples were analysed, of which 42 were classified as atacamite, 30 samples were classified as brochantite, and 19 samples were gangue minerals (Figure $8 \mathrm{c}$ ).

The MC21 unit has two layers, and a total of 210 samples were analysed. In layer 1 (surface level), a total of 31 samples were analysed, of which 13 samples were classified as atacamite and the remaining 18 samples were gangue minerals. In layer 2, a total of 179 samples were analysed, 121 of which were classified as atacamite, 7 were classified as brochantite, 5 were classified as azurite and 46 samples were gangue minerals (Figure 8d). Notably, only this unit contained azurite. In addition, in macroscopic observations of the azurite samples, chrysocolla and a dark mineral phase were recorded. To confirm these macroscopic observations, we used Raman spectroscopy and found that the samples contained azurite (Figure 9a), malachite (Figure 9b), manganosite (Figure 9c) and amorphous chrysocolla (Figure 9d).

\subsection{Mineralogical Maps with Automated Mineralogy (QEMSCAN)}

The modal mineralogy is summarised graphically in Figure 10 and numerically in Table 3. The samples contain a mixture of copper mineralisation and gangue minerals (e.g., silicates). Cu mineralisation extent varies between 0.43\% (CDG960Q3) and 47.51\% (CDG960Q5) and the mineral species present are mostly chrysocolla, atacamite and brochantite, except in sample CDG960Q5, where Cu mineralisation is mainly attributed to minerals such as cuprite/tenorite and chalcocite/digenite (Figure 11, Table 4). The content of other minerals is varied, with some samples containing Fe oxides, for example, CDG960Q1, which has an Fe oxide content of $0.31 \%$ (Figure 12, Table 5).

Table 3. QEMSCAN ${ }^{\circledR}$ modal mineralogy: grouped by Cu-bearing mineral and common gangue minerals.

\begin{tabular}{cccccc}
\hline Mineral Mass (\%) & CDG960Q01 & CDG960Q02 & CDG960Q03 & CDG960Q04 & CDG960Q05 \\
\hline Chalcocite/Digenite & 0.34 & 0.02 & 0.00 & 0.43 & 7.67 \\
Covellite & 0.00 & 0.00 & 0.00 & 0.03 & 0.38 \\
Native Copper & 0.00 & 0.00 & 0.00 & 0.00 & 2.00 \\
Chrysocolla & 0.22 & 1.96 & 0.65 & 2.86 & 0.00 \\
Cuprite/Tenorite & 0.00 & 0.00 & 0.08 & 0.01 & 17.52 \\
Malachite/Azurite & 0.00 & 0.01 & 0.06 & 0.11 & 2.36 \\
Brochantite & 0.00 & 0.00 & 0.00 & 2.38 & 0.17 \\
Atacamite & 0.30 & 0.00 & 0.02 & 0.17 & 0.66 \\
Other Cu Minerals & 0.14 & 0.01 & 0.19 & 1.56 & 8.24 \\
Cu-bearing Phyllosilicates & 0.40 & 0.33 & 0.09 & 0.10 & 0.07 \\
Cu-bearing Fe Oxide/Hydroxides & 0.02 & 0.04 & 0.11 & 0.97 & 5.62 \\
\hline
\end{tabular}


Table 3. Cont.

\begin{tabular}{cccccc}
\hline Mineral Mass (\%) & CDG960Q01 & CDG960Q02 & CDG960Q03 & CDG960Q04 & CDG960Q05 \\
\hline Hematite & 0.22 & 0.00 & 0.00 & 0.00 & 0.01 \\
Other Fe Oxides/Hydroxides & 0.02 & 0.00 & 0.01 & 0.00 & 0.00 \\
Gypsum/Anhydrite/Bassanite & 4.95 & 0.23 & 0.01 & 0.01 & 0.01 \\
Alunite & 20.43 & 0.01 & 0.01 & 0.01 & 0.81 \\
Quartz & 43.14 & 92.05 & 90.96 & 56.42 & 8.86 \\
Feldspars (Orthoclase, Plagioclase) & 11.72 & 0.63 & 0.65 & 27.27 & 0.81 \\
Kaolinite Group & 5.56 & 0.01 & 0.01 & 0.43 & 0.14 \\
White Micas (Muscovite, Sericite and Illite) & 5.57 & 4.23 & 6.71 & 4.62 & 7.83 \\
Smectite Group (Montmorillonite, Nontronite) & 3.91 & 0.01 & 0.02 & 0.10 & 0.07 \\
Pyrophyllite/Andalusite & 2.51 & 0.01 & 0.01 & 0.03 & 0.04 \\
Others & 0.32 & 0.22 & 0.29 & 0.26 & 0.20 \\
Total & 100.00 & 100.00 & 100.00 & 100.00 & 100.00 \\
\hline
\end{tabular}

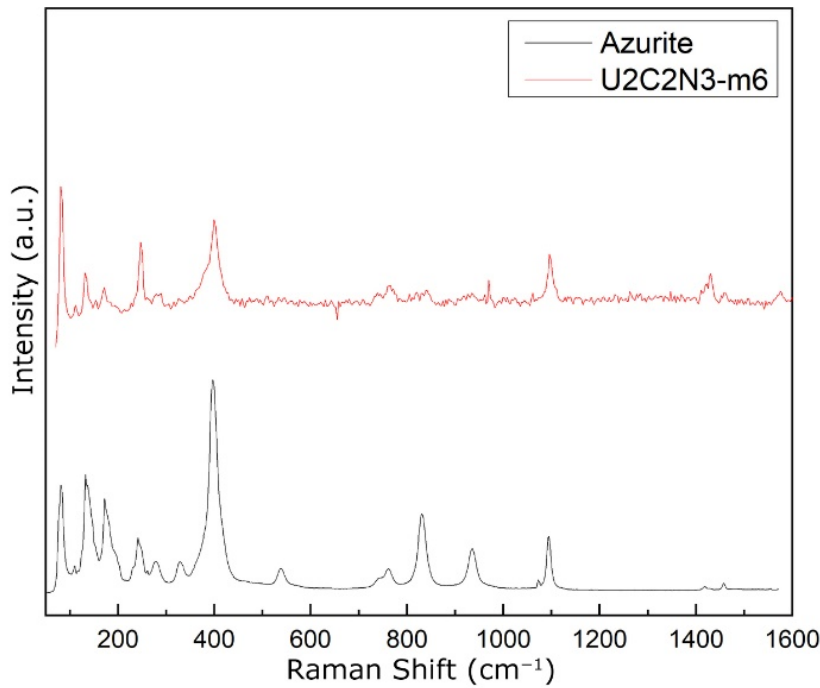

(a)

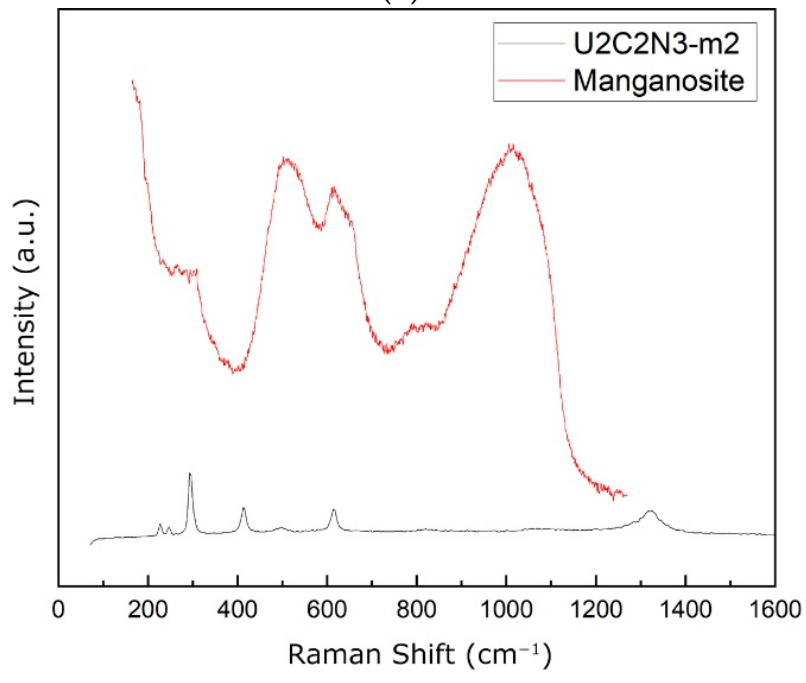

(c)

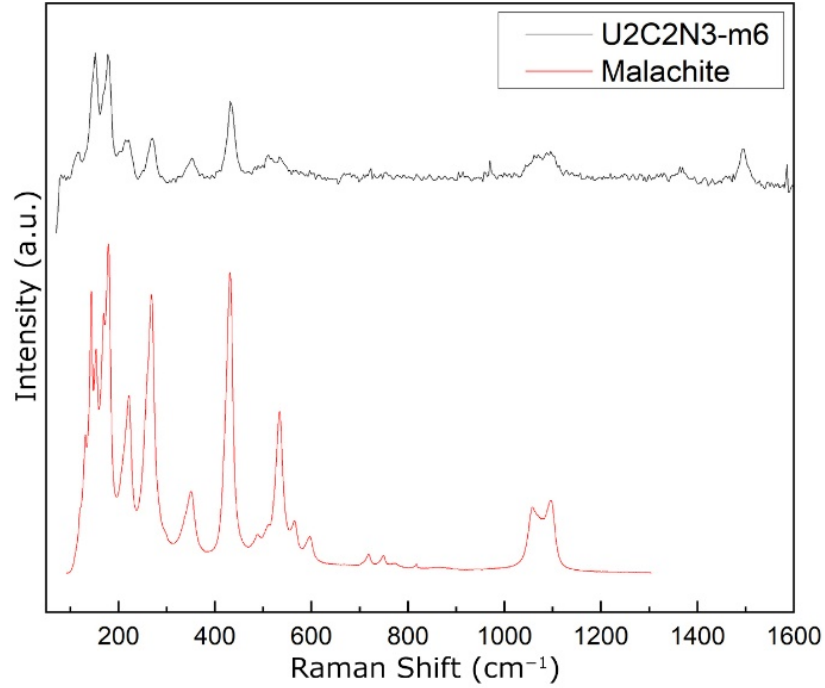

(b)

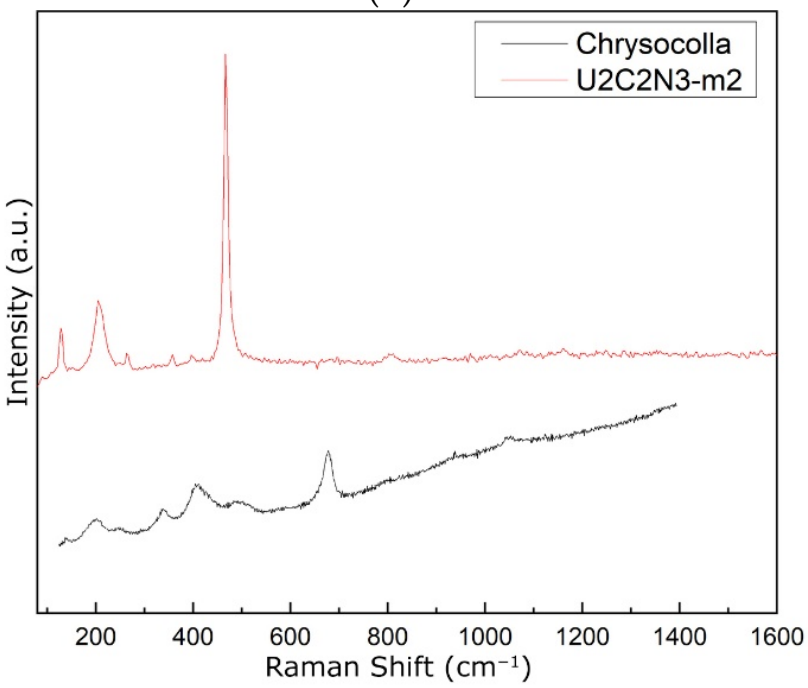

(d)

Figure 9. Raman spectrum. (a) azurite; (b) amorphous malachite; (c) manganosite; (d) amorphous chrysocolla. 


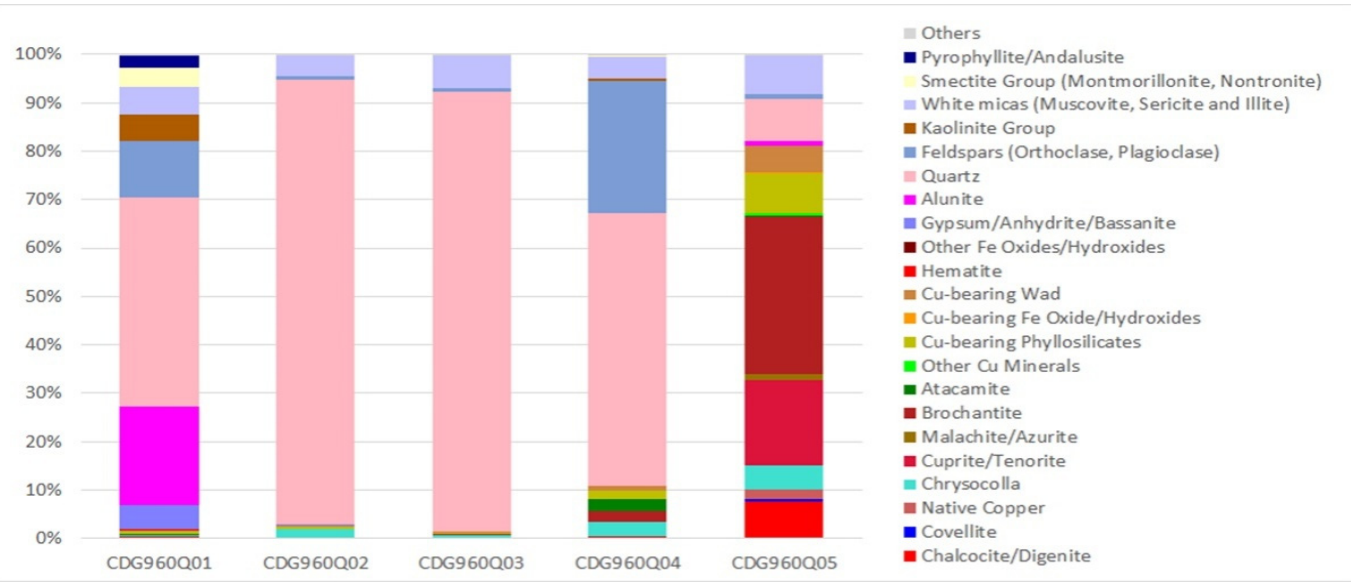

Figure 10. QEMSCAN modal mineralogy: grouped by Cu-bearing mineral and common gangue minerals. Samples came from the following sites: CDG960Q01: Chu-2 (located close to Chuquicamata-Radomiro Tomic mining district). CDG960Q02: Chu-4 (located close to Chuquicamata-Radomiro Tomic mining district). CDG960Q03: RPC (Pukara de Turi). CDG960Q04: MC2 (Pukara de Turi). CDG960Q05: AB-20 (located close to El Abra-Conchi mining district).

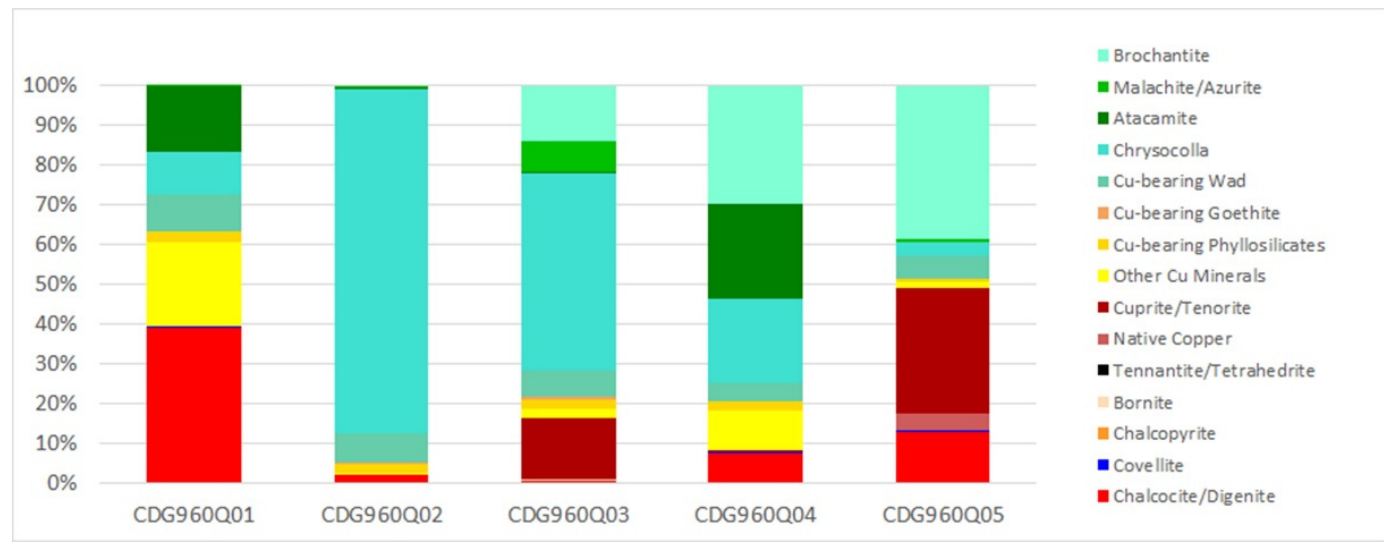

Figure 11. QEMSCAN modal mineralogy: distribution of Cu supply by mineral species. Samples came from the following sites: CDG960Q01: Chu-2 (located close to Chuquicamata-Radomiro Tomic mining district). CDG960Q02: Chu-4 (located close to Chuquicamata-Radomiro Tomic mining district). CDG960Q03: RPC (Pukara de Turi). CDG960Q04: MC2 (Pukara de Turi). CDG960Q05: AB-20 (located close to El Abra-Conchi mining district).

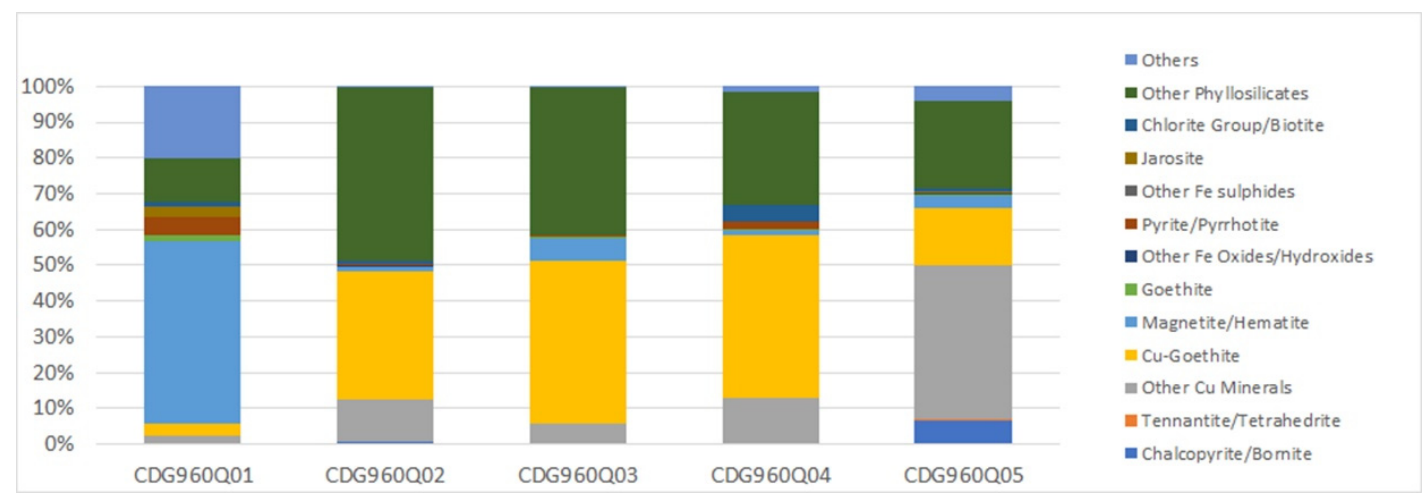

Figure 12. QEMSCAN modal mineralogy: distribution of Fe supply by mineral species. Samples came from the following sites: CDG960Q01: Chu-2 (located close to Chuquicamata-Radomiro Tomic mining district). CDG960Q02: Chu-4 (located close to Chuquicamata-Radomiro Tomic mining district). CDG960Q03: RPC (Pukara de Turi). CDG960Q04: MC2 (Pukara de Turi). CDG960Q05: AB-20 (located close to El Abra-Conchi mining district). 
Table 4. QEMSCAN modal mineralogy: distribution of Cu supply by mineral species.

\begin{tabular}{|c|c|c|c|c|c|}
\hline Mineral Mass (\%) & CDG960Q01 & CDG960Q02 & CDG960Q03 & CDG960Q04 & CDG960Q05 \\
\hline Chalcocite/Digenite & 0.27 & 0.01 & 0.00 & 0.34 & 6.06 \\
\hline Covellite & 0.00 & 0.00 & 0.00 & 0.02 & 0.26 \\
\hline Chalcopyrite & 0.00 & 0.00 & 0.00 & 0.00 & 0.01 \\
\hline Bornite & 0.00 & 0.00 & 0.00 & 0.00 & 0.00 \\
\hline Tennantite/Tetrahedrite & 0.00 & 0.00 & 0.00 & 0.00 & 0.02 \\
\hline Native Copper & 0.00 & 0.00 & 0.00 & 0.00 & 2.00 \\
\hline Cuprite/Tenorite & 0.00 & 0.00 & 0.07 & 0.00 & 14.97 \\
\hline Other Cu Minerals & 0.14 & 0.00 & 0.01 & 0.45 & 0.68 \\
\hline Cu-bearing Phyllosilicates & 0.02 & 0.02 & 0.01 & 0.10 & 0.47 \\
\hline Cu-bearing Goethite & 0.00 & 0.00 & 0.00 & 0.00 & 0.00 \\
\hline Cu-bearing Wad & 0.06 & 0.06 & 0.03 & 0.21 & 2.67 \\
\hline Chrysocolla & 0.07 & 0.66 & 0.22 & 0.95 & 1.61 \\
\hline Atacamite & 0.11 & 0.00 & 0.00 & 1.07 & 0.10 \\
\hline Malachite/Azurite & 0.00 & 0.00 & 0.03 & 0.01 & 0.36 \\
\hline Brochantite & 0.00 & 0.00 & 0.06 & 1.32 & 18.30 \\
\hline Total & 0.69 & 0.76 & 0.43 & 4.48 & 47.51 \\
\hline
\end{tabular}

Table 5. QEMSCAN modal mineralogy: distribution of Fe supply by mineral species.

\begin{tabular}{cccccc}
\hline Minerals & CDG960Q01 & CDG960Q02 & CDG960Q3 & CDG960Q4 & CDG960Q5 \\
\hline Chalcopyrite/Bornite & 0.00 & 0.00 & 0.00 & 0.00 & 0.02 \\
Tennantite/Tetrahedrite & 0.00 & 0.00 & 0.00 & 0.00 & 0.00 \\
Other Cu Minerals & 0.01 & 0.01 & 0.01 & 0.01 & 0.11 \\
Cu-Goethite & 0.01 & 0.02 & 0.05 & 0.05 & 0.04 \\
Magnetite/Hematite & 0.16 & 0.00 & 0.01 & 0.00 & 0.01 \\
Goethite & 0.00 & 0.00 & 0.00 & 0.00 & 0.00 \\
Other Fe Oxides/Hydroxides & 0.00 & 0.00 & 0.00 & 0.00 & 0.00 \\
Pyrite/Pyrrhotite & 0.02 & 0.00 & 0.00 & 0.00 & 0.00 \\
Other Fe Sulphides & 0.00 & 0.00 & 0.00 & 0.00 & 0.00 \\
Jarosite & 0.01 & 0.00 & 0.00 & 0.00 \\
Chloride Group/Biotite & 0.00 & 0.00 & 0.00 & 0.00 & 0.00 \\
Other Phyllosilicates & 0.04 & 0.03 & 0.00 & 0.00 \\
Others & 0.06 & 0.00 & 0.06 & 0.11 & 0.00 \\
Total & 0.31 & 0.06 & &
\end{tabular}

Mineral fragments collected from the mining sites have textures and mineralogies which are macroscopically very similar to those found in the Pukara de Turi excavations. These findings were confirmed by analytical results using automated mineralogy (QEMSCAN).

The samples exhibit a wide range of copper minerals as well as gangue mineralogy. Although these results do not indicate the mineralisation percentages of the parent sources, they can, nonetheless, be used as a clear guide for comparison.

Through this technique, we verified that the mineralised rock fragment found in the RPC site has the same texture and mineralogy as a fragment from the archaeological site Chu-4 [7,56], located very close to the active Chuquicamata mine, one of the largest copper mines in the world. The fragment from the RPC site (Figure 13a) is dominated by quartz (90.9\%); in addition, the sample contains $0.65 \%$ feldspars, $0.65 \%$ chrysocolla and $6.71 \%$ white micas (muscovite, sericite and illite). In comparison, the sample from the Chu-4 site (Figure 13b) shows very similar mineral content, specifically $92.05 \%$ quartz, $0.63 \%$ feldspars, $1.96 \%$ chrysocolla and $4.23 \%$ white micas. 


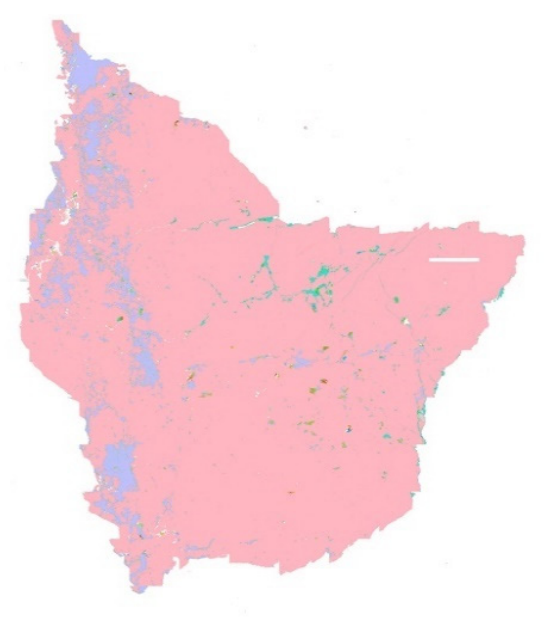

(a)

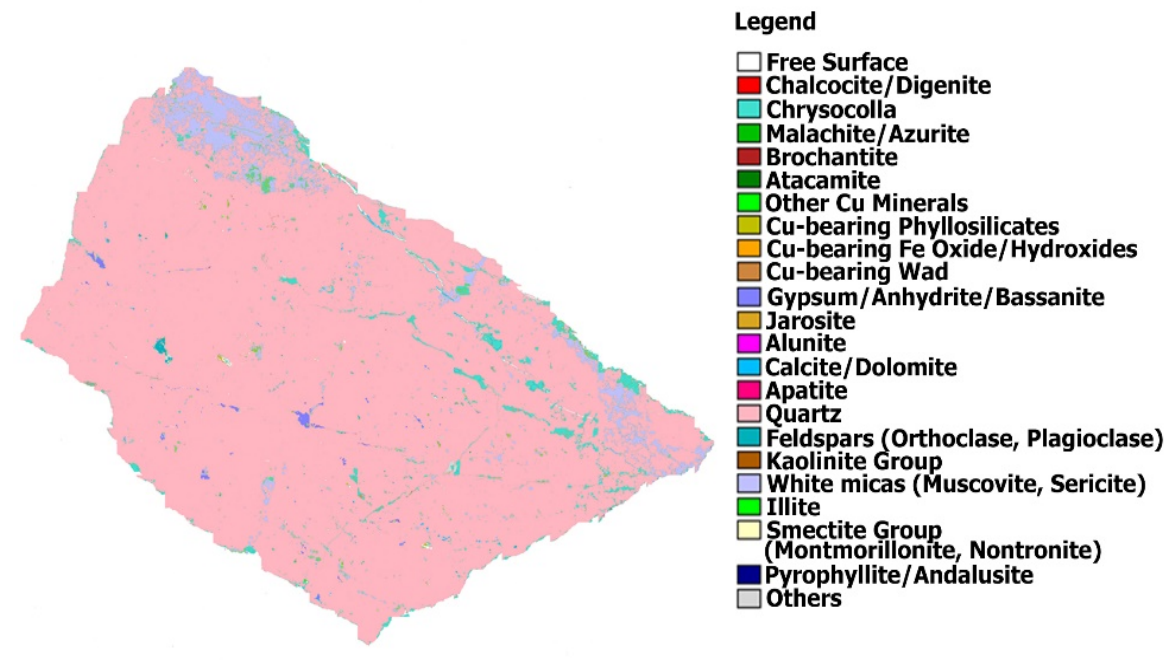

(b)

Figure 13. QEMSCAN results (2500 $\mu \mathrm{m}$ scale view). Both samples show similar percentages of mineralisation in quartz, feldspars, white micas and chrysocolla. (a) Sample CDG960Q03, which corresponds to a fragment found in an Inca architecture of the Pukara de Turi (RPC). (b) Sample CDG960Q02 corresponding to a mineral found in the Chu-4 (located close to Chuquicamata-Radomiro Tomic mining district).

In addition, we analysed one mineral fragment from the archaeological site AB-20 [7] (located very close to the pre-Hispanic mining district El Abra-Conchi) and two mineral fragments from the MC2 excavation of Pukara de Turi. The selected samples are macroscopically very similar (Figure 14a,b). Both show evident copper mineralisation (brochantite (18,30\%); cuprite/tenorite (14.97\%); chalcocite/digenite (6.06\%); Cu-bearing wad (2.67\%); native copper $(2.00 \%)$; chrysocolla $(1.61 \%)$ in a quartziferous host rock with iron oxides. The samples mineralogy was confirmed using QEMSCAN automated mineralogy (Figure 14c).

Finally, we analysed a sample from Chu-2 (located close to the Chuquicamata-Radomiro Tomic mining district $[7,56]$ ) (Figure $15 b(2)$ ) and compared it with a sample from the MC2 excavation of Pukara de Turi (Figure 15b(1)), as both are macroscopically very similar (Figure 15a(1),(2)). The sample from Pukara de Turi has a high percentage of gangue minerals (27.27\% feldspars and $56.42 \%$ quartz), whereas the sample from the Chu-2 site also contains alunite ( $11.72 \%$ feldspars, $43.14 \%$ quartz and $20.43 \%$ alunite). Therefore, although both samples macroscopically resemble each other, their mineralogies differ. However, a relationship between the two samples cannot be ruled out; alunite is an alteration mineral formed by the reaction of acid with a rock rich in potassium feldspars or orthoclase. This suggests that the two samples may be genetically similar; the rock from the archaeological excavation at MC2 in Pukara de Turi is the fresh, unaltered rock, while the rock from the Chu-2 site is the same rock type but with a degree of alteration, where a percentage of the feldspars are altered to alunite.

\subsection{Technological Study of the Copper Minerals}

After a technological study, it was found that the main objective of the production appeared to obtain small angular fragments of atacamite/brochantite up to $5 \mathrm{~mm}$ in length.

The exceptional finding of a core in this raw material (Complex 11, Room 279) suggests that the production modes were based on the roughing of single-platform cores with an orthogonal débitage surface distributed along one of the faces (Figure 16). The technical negatives of the detachments on this piece, as in the related knapping debris, suggest that the predominant technique of detachment was direct hard percussion, probably on an anvil at an angle between $80^{\circ}$ and $90^{\circ}$ This mode of processing allows split fractures of the raw material to be obtained (also known as bipolar knapping in the Anglo-Saxon literature $[53,57])$. 
Based on our experimental tests, despite the scarce samples, this technique appears to be the most suitable for working on heterogeneous rocks with high crystal content.

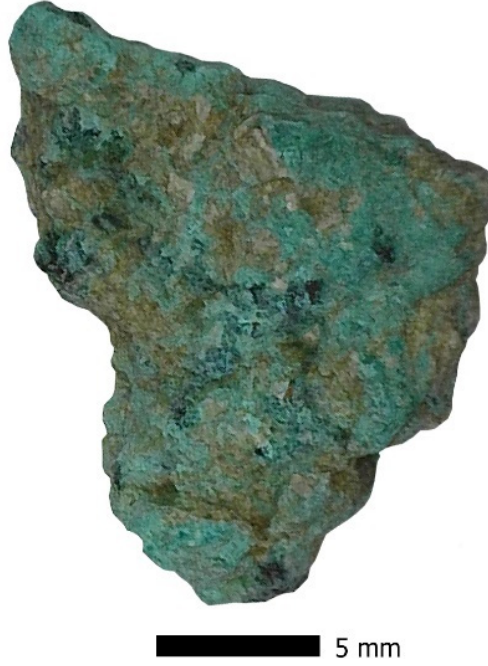

(a)
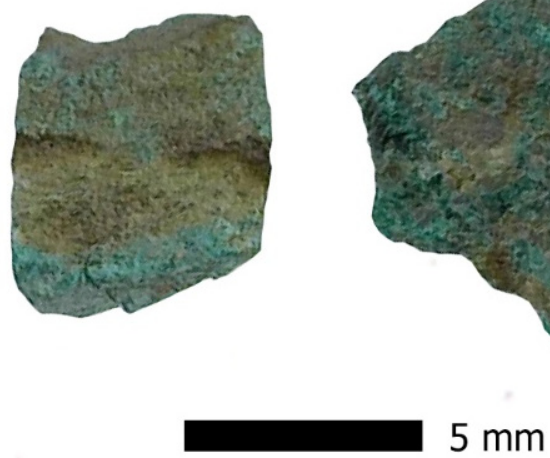

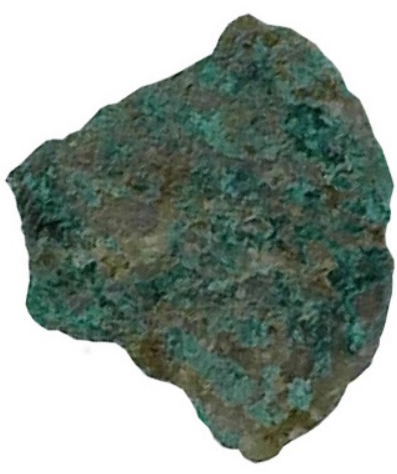

$5 \mathrm{~mm}$

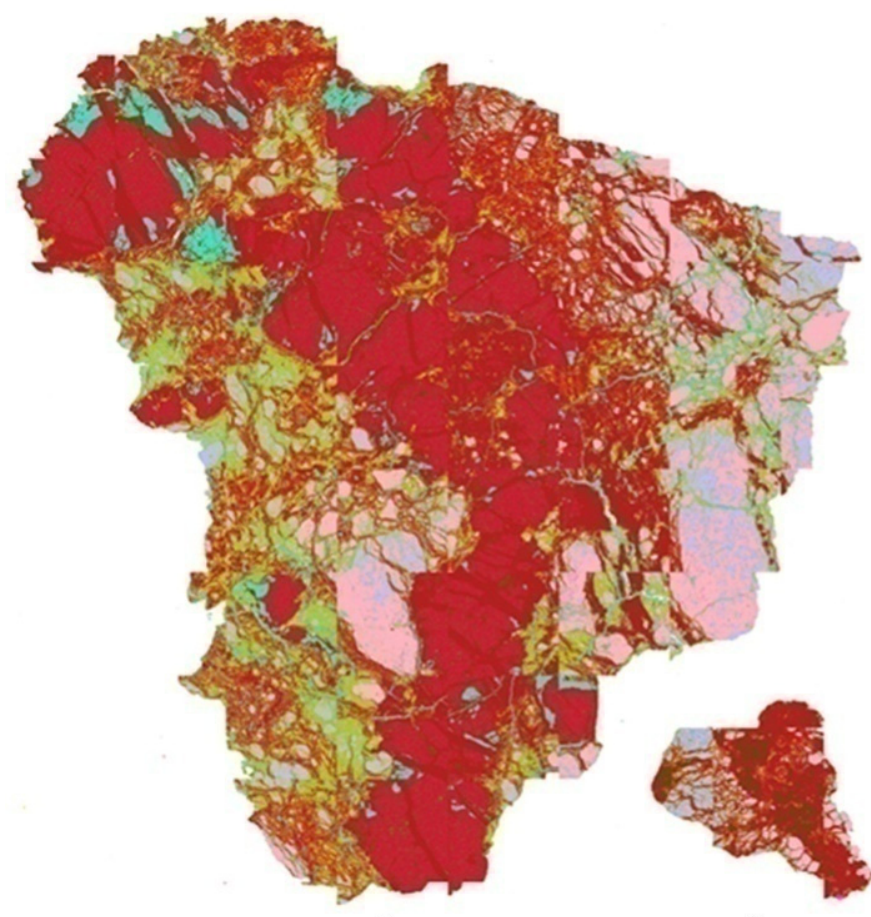

1

2

(b)

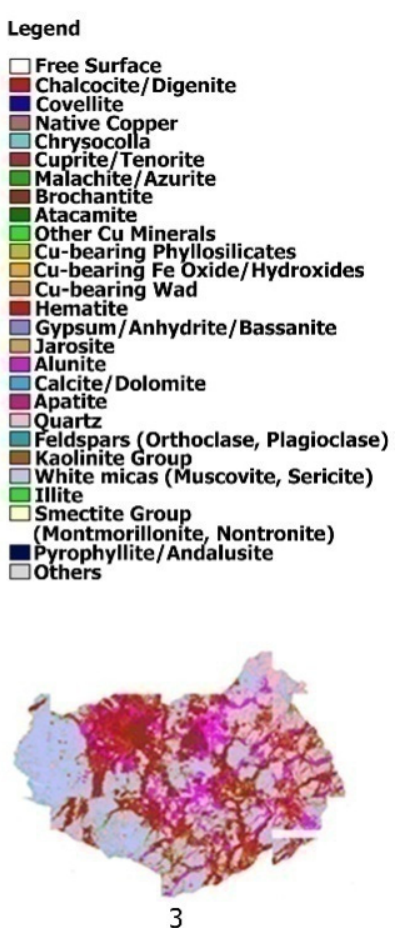

(c)

Figure 14. QEMSCAN results for the samples from AB-20 (located close to El Abra-Conchi mining district) and from the MC2 excavation of the Pukara de Turi. The samples macroscopically present similarities that were corroborated by the analyses carried out. (a) Macroscopic photograph of sample CDG960Q05 from site AB-20. (b) Macroscopic photographs of sediments from MC2. (c) Mineralogical maps: (1) sample CDG960Q05 (sample of approximately $2 \mathrm{~cm}$ in its maximum dimension, $2500 \mu \mathrm{m}$ scale), (2) sample Turi_U1C2N5_x16 (sample of approximately $0.5 \mathrm{~cm}$ in its maximum dimension, $2500 \mu \mathrm{m}$ scale), (3) sample Turi_U1C2N2_3 (sample approximately $0.7 \mathrm{~cm}$ in maximum dimension, scale $2500 \mu \mathrm{m}$ ). 


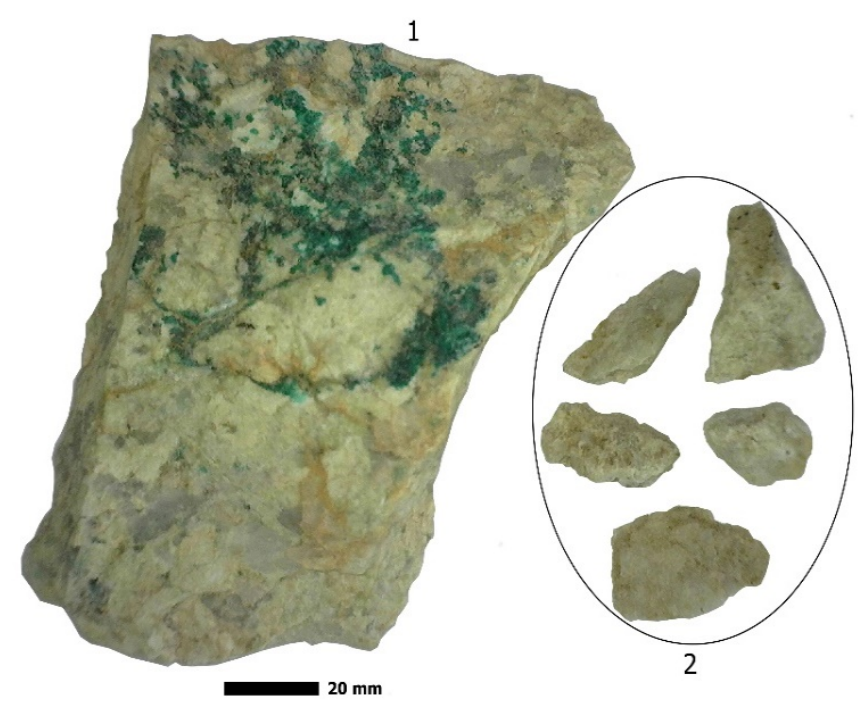

(a)

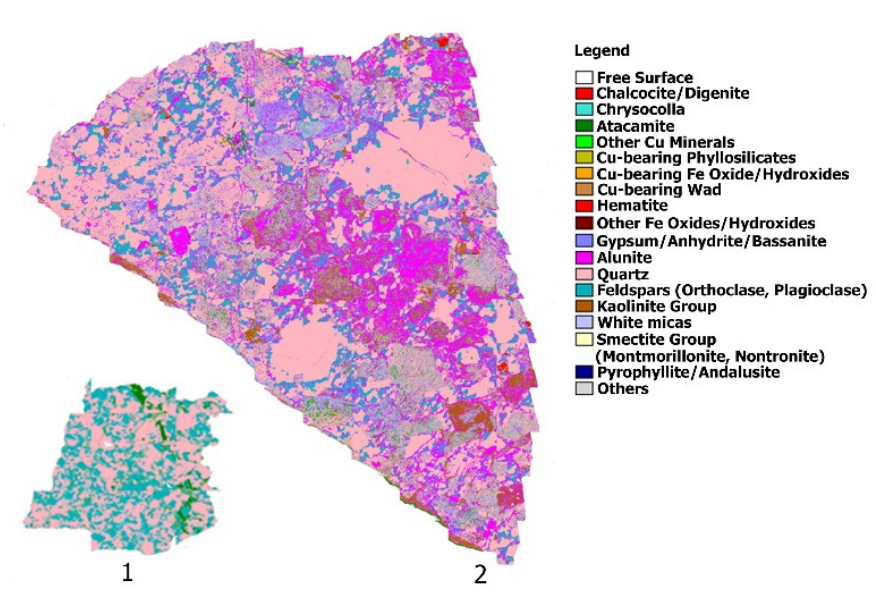

(b)

Figure 15. QEMSCAN results for samples from Chu-2 (located close to Chuquicamata-Radomiro Tomic mining district) and from the MC2 excavation of the Pukara de Turi. (a) Samples macroscopically present similarities that were corroborated by the analyses carried out: (1) macroscopic photograph of sample CDG960Q01 from site Chu-2, (2) macroscopic photographs of sediments from MC2. (b) Mineralogical maps: (1) sample CDG960Q04 (sample from MC2 of approximately $0.2 \mathrm{~cm}$ in its maximum dimension, $2500 \mu \mathrm{m}$ scale), (2) sample CDG960Q01 (sample from Chu-2 of approximately $1 \mathrm{~cm}$ in its maximum dimension, $2500 \mu \mathrm{m}$ scale).
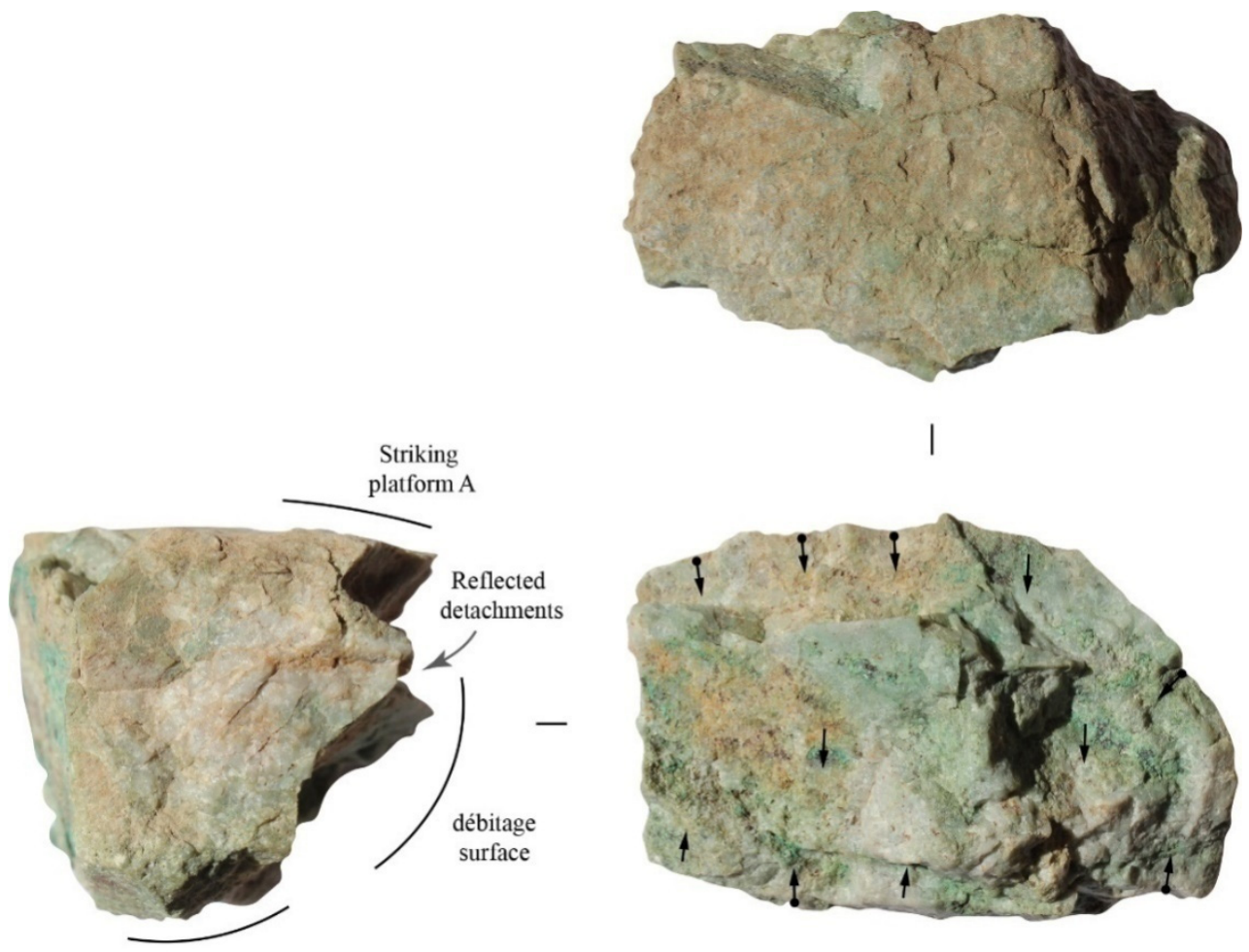

Striking platform B

(anvil)

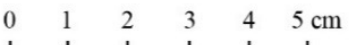

Figure 16. Simple platform core with split fractures and reflected detachments.

The blanks obtained were mainly backed flakes or slices that provided more manageable raw material volumes. However, both the detachment technique and the heterogeneity 
of the raw material led to a high fracture rate and reflected and step damage, along with a large amount of small and medium debris. The blanks and resulting fragments were subsequently crushed and ground on a hard surface using a grinding stone, with the aim of selecting and isolating the areas with the highest percentage of ore and separating them from the less productive areas. In this phase of the operational chain, the final products were obtained. The abrasion and rounding of angles, in addition to the cracked surfaces observed in most fragments under a magnifying glass, may have originated during this processing phase and, therefore, could serve as discriminant criteria. However, taphonomic processes should not be ruled out; mechanical weathering may have occurred during transport due to the percussion of fragments or due to post-depositional factors such as trampling and wind abrasion.

\section{Discussion}

Throughout the total samples analysed, a consistent atacamite/brochantite ratio is observed in all the layers of the units. This association of minerals is a common paragenesis recorded in the copper veins of the Atacama Desert. Quartz fragments with atacamite and/or brochantite are part of the gangue contained in mineralised veins. The size of the samples is homogeneous with a maximum dimension not exceeding $10 \mathrm{~mm}$, indicating that these fragments were previously crushed. The 568 samples analysed indicate that those selected from the vein were atacamite and that the quartz was a waste product. The results also indicate that the atacamite/brochantite mineral association is present in all the mineralised samples analysed, suggesting that the crushed minerals from the Pukara de Turi come from the same mineral source. Furthermore, the vein sample found in Complex 11 is compositionally identical to the crushed material from the units and allows some of the characteristics of the source to be inferred. Although these results do not represent samples from an in situ mine, they can, nonetheless, be used as a guide to relate the samples to their exact source.

To constrain the geographical origin of the samples, specific analytical techniques (i.e., PIXE, Radiogenic and Stable Isotopy) are required to understand the geochemical markers of specific mineral sources. However, recent studies have shown that isotopes in veins do not necessarily match those obtained in the porphyry copper ore; there may also be no large isotopic variations between geographically distant locations [58]. Instead, the analytical techniques applied in this study represent an adequate tool to search for other characteristics in the studied minerals. First, it is necessary to establish the mineral associations-generally, these characteristics will allow us to rule out possible geological sources and narrow down potential provenances. Although mineral-source correlations could not be found in all cases, thanks to the mineralogical study and analytical techniques usually applied in geology, we were able to infer archaeological conclusions that allowed us to determine the minerals' raw materials and understand their consumption. In provenance studies, it is necessary to compare more than one sample from the same deposit. Furthermore, there is the potential that veins from large mines may no longer exist; thus, it is necessary to access museum collections that may hold samples of old veins from the 19th or early 20th century to make comparisons with ores from pre-Hispanic mining sites. This aspect is essential—contemporary mining does not necessarily represent the minerals that were mined in ancient times. There are few pre-Hispanic mines that have not been destroyed with the advancement of modern mining. El Abra and Cerro Verde are exceptional, and their conservation is no small feat for pre-Hispanic mining archaeology. However, the mineral wealth of the Atacama Desert presents a great challenge, as copper deposits are not an anomaly. For example, atacamite and brochantite are common minerals in the supergene zones of different deposits in northern Chile, such as those at El Abra, Mantos Blancos, Chuquicamata, Radomiro Tomic, La Escondida, among others [23,24,59-63]. While the geological literature is a guide and a first start in the search for provenance, the integration of these constraints with archaeological information will allow us to come closer to defining the minerals' geological sources. 


\subsection{Atacamite/Brochantite Association}

Some aspects of mineral formation are relevant to understanding the nature of the atacamite/brochantite ratio. Atacamite is a copper hydroxy-chloride mineral $\left(\mathrm{Cu}_{2} \mathrm{Cl}(\mathrm{OH})_{3}\right)$ present in the supergene mineralisation zone; its formation, as a result of supergene enrichment, requires a hyper-arid climate, and the water filtering through the deposit must also be relatively saline [61,62]. Atacamite/brochantite paragenesis is fairly common as both minerals precipitate under alkaline conditions $[40,62]$. There is a consistent relationship observed between atacamite/brochantite in all units $(\sim 80 \% / 20 \%$, respectively) and the vein fragment examined in this study. This ratio is consistent with the stability fields of atacamite, which are wider than those of brochantite [62]; therefore, more atacamite is present than brochantite because the precipitation of brochantite is limited to certain conditions, whereas atacamite precipitates in a wider range of conditions. Another important factor is that atacamite and brochantite are intergrown-this suggests co-precipitation; thus, the ratio of these minerals would more likely result from a specific ratio of chlorite to sulphate in the meteoric water. Both minerals display intergrowth textures, meaning that it would be exceedingly difficult to manually separate these them, supporting the hypothesis that although they are crushed fragments, the relationship between the two mineral phases is natural rather than anthropic in origin. However, the copper content in both minerals is similar, i.e., $59.51 \%$ in atacamite and $56.20 \%$ in brochantite; therefore, if manual separation had taken place, it would not have been related to the grade of the minerals.

\subsection{Azurite/Chrysocolla Association}

For the precipitation of copper carbonates, such as azurite or malachite, the circulation of carbonate-rich, copper sulphate-bearing waters is required. These minerals precipitate, for example, in sedimentary environments where carbonate sources exist under $\mathrm{pH}$-neutral or alkaline conditions [40]. These carbonates, along with mineraloids such as chrysocolla, commonly occur together and comprise paragenetically late-maturing minerals.

The stability field of azurite does not match or overlap with those of atacamite and brochantite [62]; therefore, these minerals have different formation conditions. This suggests that the samples showing an atacamite/brochantite mineral association belong to a different source from those with the azurite/chrysocolla association. The azurite/chrysocollaassociated samples found in the MC21 unit are, therefore, anomalous compared to the bulk of the samples we examined and likely do not originate from the same source as the other minerals studied.

Recent associative surveys with the indigenous community of Caspana in their territory allowed us to review mineralogy present in four mining pits. Three of them were recently exploited (Rio Pila pit, San Santiago mine and the current Cerro Verde mine), and one of them was originally exploited during pre-Hispanic times (Cerro Verde mine) [47]. Macroscopic study of the rocks in these locations and Raman spectroscopy confirmed that all the pits present rocks with azurite/chrysocolla as their main mineral association, in addition to manganosite, which is a characteristic mineral of these samples.

We suggest that the geological source of the minerals with the azurite/chrysocolla association is a mining pit similar to those observed around Caspana. This mineral paragenesis is representative of this mining district and matches well with the pre-Hispanic mine at Cerro Verde [63,64].

\subsection{The Known Pre-Hispanic Ores of Atacama La Baja}

Pre-Hispanic mining districts corresponding to Late Intermediate and Late Period times have been identified at El Abra, Conchi Viejo, Cerro Verde and, possibly Chuquicamata and San Bartolo. In terms of straight-line distance, El Abra is located $68 \mathrm{~km}$ from Turi and Cerro Verde is $15 \mathrm{~km}$ from Turi, whereas Chuquicamata is located at a distance of $65 \mathrm{~km}$, Conchi Viejo at $62 \mathrm{~km}$ and San Bartolo at $54 \mathrm{~km}$ (Figure 2).

The Inca mines of El Abra are famous for their turquoise veins [14,33]; however, they are not as well known for their atacamite; a similar situation is recorded at Chuquicamata- 
Radomiro Tomic [7]. However, some samples of atacamite/brochantite in Turi may have originated from these districts. The arguments in favour of this interpretation are mainly based on the bulk macroscopic observations of all the sediments extracted from the mineral concentrations of Pukara de Turi, i.e., not only the sediments with copper mineralisation, but also of the sediments with little or no mineralisation. Based on their mineralogy and textures (Figures 13-15), these samples are comparable with some samples from the AB-20, Chu-2 and Chu- 4 excavations, all of them sites associated with the pre-Hispanic exploitation of El Abra-Conchi and Chuquicamata-Radomiro Tomic. Notably, no turquoise was analysed in any of the Turi samples of the structures we studied in this work, a mineral in high demand during pre-Hispanic times for lapidary work, which is characteristic of the El Abra, Chuquicamata and San Bartolo pits. A little further south, the pre-Hispanic district of San Bartolo does present atacamite/brochantite. However, the occurrence and host rock of the mineral is different. Specifically, the copper mineralisation is disseminated and hosted in sandstones; in addition, native copper and cuprite are found in these locations. It would appear that the material targeted in Turi was specifically high-grade ores, such as atacamite, rather than turquoise-type ores. It is also important to note that the sediments with mineralisation in Pukara de Turi are not eroded; therefore, they do not seem to have arrived there by transport, but rather, they have straight edges, indicating that they may have undergone a previous grinding process.

The observation of minerals with an azurite/chrysocolla association in Turi is the first direct evidence of the presence of minerals from one Inca mining district in another Inca site. Although the azurite specimens only comprise a few samples and do not represent the majority mineral of Turi, they are nonetheless an important finding. In this context, the nature of the Cerro Verde site is of particular interest. This site was one of the most important provincial centres built by the Incas in the Loa River basin and has a direct relationship with mining [65]. The mining settlements are connected to the $u s h n u$, the ceremonial area of Cerro Verde, via the Inca Road, and there is also a pre-Hispanic mining camp. As noted by [65], the ushnu has a direct relationship with the mining areas and it is proposed that this characteristic may be interpreted as a mining centre and its corresponding wak'a (sensu [66]). The ritual dimension of the raw material and its precise location in the territory was a potentially crucial aspect of Inca mining activities that should be addressed in the future in the context of Pukara de Turi.

\subsection{Copper Mineral Technologies and the Production Context}

Unlike the lapidary industries of Atacama, no evidence of direct percussion (hard and soft) or pressure were recorded. Objects such as mineral beads, pendants or carved figures are absent from the enclosures studied in this work; however, these are probably present in other specialised areas of Turi. Considering the evidence, we suggest that the technological structure of the assemblages was related to a single operational chain that focused on the production of small angular fragments of atacamite/brochantite. The fact that only a few cores were recorded in situ, together with the absence of blanks, suggests that the initial stages of the operational chains (i.e., acquisition of the raw material, initial reduction and roughing of cores) were performed in the extraction areas themselves or in intermediate workshops.

The reduction of blocks through split fracturing did not necessarily require greater skill in technique and had the objective of obtaining blanks of a determined morphology according to the final product. We consider that this was likely an intermediate stage to obtain more suitable volumes of raw material for transport and to facilitate grinding in the workshops where small angular fragments were obtained. According to our study, only the final stages of production were carried out in Turi, i.e., those related to grinding, selection and use in offerings, implying a high spatial segmentation of the operational chains probably related to a social division of the production process.

In this context, copper mineral technology would be considered a ritual technology (production rituals, sensu [67]), which was an integral part of the productive technologies 
in the Andes. Enabling the non-human agents that inhabit the Andean world was seen as fundamental to the success of daily and productive activities. In this sense, copper technology was a true ritual technology, as the mineral constituted a central substance used in the various production rituals of the Atacameño Andean agro-pastoralists, miners and caravaners to ensure the success of their various activities and needs.

\section{Conclusions}

By systematically evaluating the characteristics, chronology, contextual associations, architecture and spatial distributions of the main areas where copper minerals were offered in the Pukara de Turi, we can confirm that a minimum of two entirely different types of mineralisation were used: a vein of atacamite/brochantite and another of azurite/chrysocolla. In the first case, mineralisation occurs in veins. Such mineralised quartz veins are characteristic of small-scale mining in northern Chile and their associated mineralisation generally originates from the circulation of hydrothermal fluids.

The azurite/chrysocolla association appears to belong to the same mineral association found in the Cerro Verde district [47], which is probably the source of these samples. The study of copper mineral powder from an Inca site in Caspana (a few kilometres from Cerro Verde) yielded atacamite [48]. The origin of the atacamite/brochantite may lie within the Late Eocene-Oligocene Metallogenic belt where the districts of Chuquicamata- Radomiro Tomic and El Abra-Conchi are located and where atacamite/brochantite veins have been described. Some mineral products from Turi are similar to those of Chuquicamata-Radomiro Tomic and El Abra-Conchi, based on our analysis of copper minerals from AB-20, Chu-2 and Chu-4. However, based on the macroscopic characteristics of the samples, from Pukara de Turi, there is undoubtedly at least a third set of minerals that originate from a vein of translucent quartz with vetiform atacamite. This mineral association does not present similarities with those of known mining sites, so we must continue searching for pits (for example, in the Salado River area) that present similarities to these minerals, which would allow us to make comparisons to get closer to the geological source.

Complementarily, the use of an extensive categorical database ( 280 samples) of mineral types (atacamite, brochantite and azurite) as an exploratory random sampling technique can reveal unobserved mineral associations in the analysed archaeological batch. As an example, following a basic analysis of categorical data proposed by [68], the minimum number of samples needed to satisfy the dominant proportion of atacamite/brochantite $(\sim 80 \% / 20 \%)$ is $\sim 400$ samples with a maximum error of $\pm 5 \%$ at the $99 \%$ confidence level, suggesting a reasonable adjustment to the preliminary sampling design proposed.

Our systematic research in the Pukara de Turi documented various indigenous ritual practices associated with copper minerals. To understand the types of copper minerals that were consumed and how they circulated, the starting point of the study was the development of a comprehensive methodology, developed based on archaeological and geochemical perspectives in addition to constraints from indigenous geology, in one of the largest copper-producing environments in the world. This protocol will help contribute to understanding the production, demand and consumption of minerals through an improved understanding of the changes and continuities in the mining districts and pre-Hispanic circulation areas of copper minerals in the Atacama Desert.

The development of an ad hoc methodology for mineral analysis in archaeological sites allows data to be interpreted more reliably. In particular, the application of nondestructive analyses is paramount for samples originating from archaeological sites. The description of such minerals allows improved future comparisons to be made with copper minerals from candidate source areas in the Atacama Desert. As noted above, although there are many copper veins in the region, integrating constraints from a combination of a broad selection of samples, both geological and archaeological, and the traditional geological knowledge of indigenous communities allows improved correlations to be made between districts. Although it is not the focus of this article, it is necessary to emphasise the relevance of traditional ecological knowledge specifically related to Andean geologies. 
As part of the scientific practice of contemporary geological research, it is essential to find common ground with traditional ecological knowledge through horizontal scientific partnerships with local communities, in particular, those that preserve the indigenous mining heritage, especially from contemporary mining extractivism.

The geological study of archaeological samples is important to adequately reconstruct the long history of human interaction with minerals, how these interactions developed, and changes in the know-how needed to identify, process and use these geological resources. Working on provenance is a matter of patience, so while there is hope in this, there is still a long life for mineralogical studies.

Author Contributions: Conceptualisation, P.S. and V.F.; methodology, P.S. and A.M.; formal analysis, J.G. and C.G.; investigation, P.S., V.F., F.H., B.M. and R.L.; resources, F.H., D.S., C.P.-O., A.T., P.S. and V.F.; writing —original draft preparation, P.S.; writing—review and editing, P.S., V.F., D.S., F.H. and R.L.; project administration, F.H., D.S., C.P.-O., A.T. and V.F. All authors have read and agreed to the published version of the manuscript.

Funding: Field study of the challas was supported by an IIE Fulbright award to Frances Hayashida and funds from the University of New Mexico Snead-Wertheim Endowed Lectureship in Anthropology and History. The analyses were supported by the Agencia Nacional de Investigación y Desarrollo (ANID)/BECA DOCTORADO NACIONAL/2018-21181070, Proyecto FONDECYT 1201603 "Paisajes mineros prehispánicos en el desierto de Atacama: hacia un estudio del uso de los minerales de cobre y su vinculación con la producción de tecnologías rituales" and Grant CONICYT-USA 2013/0012 "Water management and agrohydraulic systems in desert environments: the upper Loa from A.D. 1000-1500".

Data Availability Statement: All data derived from this research are presented in the enclosed figures and tables.

Acknowledgments: The analyses presented were conducted at Unidad de Equipamiento CientíficoMAINI at Universidad Católica del Norte, Antofagasta, Chile. In addition, we would like to thank the directive of the Comunidad Atacameña de Caspana (2020-2021) and of the community of AyquinaTuri (2018). Special thanks to Lautaro Núñez for the Abra/Chuquicamata samples. In addition, thanks to Mariela Pino, César Borie y Pastor Fábregas-Alvarez, who are part of the Turi-Topaín project. Finally, the support of doctoral grant ANID/BECA DOCTORADO NACIONAL/201821181070, Proyecto FONDECYT 1201603 "Paisajes mineros prehispánicos en el desierto de Atacama: hacia un estudio del uso de los minerales de cobre y su vinculación con la producción de tecnologías rituales" and the postdoctoral grant ANID/FONDECYT 3200772 is acknowledged.

Conflicts of Interest: The authors declare no conflict of interest. The funders had no role in the design of the study; in the collection, analyses, or interpretation of data; in the writing of the manuscript, or in the decision to publish the results.

\section{References}

1. Camus, F.; Dilles, J.H. A Special Issue Devoted to Porphyry Copper Deposits of Northern Chile. Econ. Geol. 2001, 96, 233-237. [CrossRef]

2. Figueroa, V.; Salazar, D.; Salinas, H.; Núñez-Regueiro, P.; Manríquez, G. Pre-hispanic mining ergology of northern chile: An archaeological perspective. Chungara 2013, 45, 61-81. [CrossRef]

3. Vaughn, K.J.; Tripcevich, N. An introduction to mining and quarrying in the ancient Andes: Sociopolitical, economic and symbolic dimensions. In Mining and Quarrying in the Ancient Andes: Sociopolitical, Economic and Symbolic Dimensions; Tripcevich, N., Vaughn, K., Eds.; Springer: New York, NY, USA, 2013; pp. 3-19. [CrossRef]

4. Zori, C. Extracting Insights from Prehistoric Andean Metallurgy: Political Organization, Interregional Connections, and Ritual Meanings. J. Archaeol Res. 2019, 27, 501-556. [CrossRef]

5. Berenguer, J.; Salazar, D. Territorialización del modelo minero inkaico en el río Salado: Una aglomeración productiva entre Lípez y San Pedro de Atacama. Bol del Mus Chil Arte Precolomb 2017, 22, 51-69. [CrossRef]

6. Figueroa, V.; Mille, B.; Salazar, D.; Berenguer, J.; Menzies, A.; Sapiains, P.; Cifuentes, A.; Joly, D. A major Prehispanic copper production center identified at Collahuasi, Southern Tarapacá Altiplano (Chile). Chungara 2018, 50, 557-575. [CrossRef]

7. Núñez, L. Valoración minero-metalúrgica circumpuneña: Menas y mineros para el Inka Rey. Estud Atacameños 1999, 18, 177-222. [CrossRef]

8. Núñez, L.; Grosjean, M.; Cartajena, I. The expansion of the Inka empire into the Atacama Desert. In $23^{\circ} S$ Archaeology and Environmental History of the Southern Deserts; Smith, M., Hesse, P., Eds.; National Museum of Australia Press: Canberra, Australia, 2005; pp. 324-332. 
9. Salazar, D. La producción minera en San José del Abra durante el Período Tardío Atacameño. Estud Atacameños 2008, 36, 43-72. [CrossRef]

10. Melero, D.; Salazar, D. Historia colonial de Conchi Viejo y San José del Abra, y su relación con la minería en Atacama, Norte de Chile. Rev. Hist. Indígena 2003, 7, 55-86.

11. González, L.R. El Arte Del Cobre En Los Andes Prehispánicos: Historias de Poder, Brillos y Colores. In El Arte del Cobre en el Mundo Andino; Berenguer, J., Ed.; Museo Chileno de Arte Precolombino: Santiago, Chile, 2003; pp. 8-59.

12. Lechtman, H. Andean Metallurgy in Prehistory. In Archaeometallurgy in Global Perspective: Methods and Syntheses; Roberts, B., Thornton, C., Eds.; Springer: New York, NY, USA, 2014; pp. 361-422. [CrossRef]

13. Cifuentes, A.; Figueroa, V.; Salazar, D.; Mille, B. Producción metalúrgica local y coexistencia de tecnologías metalúrgicas en San Pedro de Atacama durante el Período Medio (400-1000 DC). Chungará 2018, 50, 423-439. [CrossRef]

14. Salazar, D. El complejo Minero San José del Abra, II Región (1450-1536 d.C.). Una Aproximación a la Arqueología de la Minería. Tesis Para Optar al Grado de Magíster en Arqueología, Universidad de Chile, Santiago, Chile, 2002.

15. Angiorama, C.I. Producción y circulación de objetos de metal en la Quebrada de Humahuaca en momentos prehispánicos tardíos. Unpublished. Ph.D. Thesis, Universidad Nacional de Tucumán, San Miguel de Tucumán, Argentina, 2003.

16. Berenguer, J. Caravanas, Interacción y Cambio En El Desierto de Atacama; Sirawi Ediciones: Santiago, Chile, 2004; p. 604. [CrossRef]

17. Nielsen, A. Armas significantes: Tramas culturales, guerra y cambio social en el Sur Andino prehispánico. Boletín del Mus Chil Arte Precolomb 2007, 12, 9-41.

18. Pimentel, G. Redes viales prehispánicas en el Desierto de Atacama. Viajeros, Movilidad e Intercambio. Unpublished. Ph.D. Thesis, Universidad Católica del Norte and Universidad de Tarapacá, San Pedro de Atacama, Chile, 2012.

19. Rees, C. Elaboración, distribución y consumo de cuentas de malaquita y crisocola durante el Período Formativo en la Vega de Turi y sus inmediaciones, subregión del río Salado, norte de Chile. In Los Tres Reinos: Prácticas de Recolección En El Cono Sur de América; Aschero, C., Korstanje, A., Vuoto, P., Eds.; Instituto de Arqueología y Museo, Universidad Nacional de Tucumán: Tucumán, Argentina, 1999; pp. 85-98.

20. Sepúlveda, M.; Figueroa, V.; Cárcamo, J. Pigmentos y pinturas de mineral de cobre en la región de Tarapacá, norte de Chile: Nuevos datos para una tecnología pigmentaria prehispánica. Estud Atacameños 2014, 1, 23-37. [CrossRef]

21. Sinclaire, C. Los sitios de "Muros y Cajas" del río Loa y su relación con el tráfico de caravanas. In Taller de Costa a Selva; Albeck, M.E., Ed.; Instituto Interdisciplinario Tilcara, Universidad de Buenos Aires: Buenos Aires, Argentina, 1994; pp. 51-76.

22. Soto, C. Tipología de cuentas de collar en la Quebrada de Tulan (Salar de Atacama): Nueva línea de evidencia para la transición arcaico-formativo. In Proceedings of the Actas Del XVII Congreso Nacional de Arqueología Chilena, Valdivia, Chile, 9 October 2006; Ediciones Kultrún: Valdivia, Chile, 2010; Volume 2, pp. 1123-1134.

23. Ulriksen, C.E. Mapa Metalogénico de Chile Entre Los $18^{\circ}$ y 34 S, Escala 1:1.000.000; Servicio Nacional de Geología y Minería: Santiago, Chile, 1990; Volume 42, p. 112.

24. Boric, R.; Díaz, F.; Maksaev, V. Geología y Yacimientos Metalíferos de La Región de Antofagasta; Servicio Nacional de Geología y Minería: Santiago, Chile, 1990; Volume 40, p. 246.

25. Sillitoe, R.H.; Mckee, E.H. Age of Supergene oxidation and enrichment in the chilean porphyry copper province. Econ. Geol. 1996, 91, 164-179. [CrossRef]

26. Brimhall, G.H.; Levi, B.; Nyström, J.O.; Enrique, T.F. Atacamite inclusions in rock-forming feldspars and copper-bearing smectites from the Radomiro Tomic mine, Chile: Copper-insoluble mineral occurrences. Econ. Geol. 2001, 96, 401-420. [CrossRef]

27. Campos, E.; Menzies, A.; Sola, S.; Hernández, V.; Riquelme, R.; Barraza, M. Mineral resources in a sustainable world, Session 10, Concentration processes in sub-surface environments, Understanding Exotic-Cu Mineralisation: Part I-Characterization of Chrysocolla. In Proceedings of the 13th SGA Biennal Meeting, Nancy, France, 24-27 August 2015; André-Mayer, A.S., Cathelineau, M., Muchez, P., Pirard, E., Sindern, S., Eds.; Volume 3, p. 1153.

28. Sapiains, P.; Menzies, A.; Figueroa, V.; Wilke, H.G.; Mille, B.; Salazar, D.; Berenguer, J. Estudio arqueomineralógico de las menas de cobre prehispánicas en Collahuasi, norte de Chile. Estud Atacameños 2020, 66, 83-103. [CrossRef]

29. Kahou, Z.S.; Brichau, S.; Poujol, M.; Duchêne, S.; Campos, E.; Leisen, M.; d'Abzac, F.X.; Riquelme, R.; Carretier, S. First U-Pb LA-ICP-MS in situ dating of supergene copper mineralization: Case study in the Chuquicamata mining district, Atacama Desert, Chile. Miner. Depos. 2021, 56, 239-252. [CrossRef]

30. Sillitoe, R.H. Epochs of intrusion-related copper mineralization in the Andes. J. S. Am. Earth Sci. 1988, 1, 89-108. [CrossRef]

31. Salazar, D. Investigaciones arqueológicas sobre la minería incaica en San José del Abra (II región, norte de chile). Xama 2002, 15, 101-117.

32. Salazar, D.; Salinas, H. Tradición y transformaciones en la organización de los sistemas de producción mineros en el norte de Chile prehispánico: San José del Abra, siglos I al XVI DC. In Mina y Metalurgia En Los Andes Del Sur Desde La Época Prehispánica Hasta El Siglo XVII; Cruz, P., Vacher, J.J., Eds.; Instituto Francés de Estudios Andinos: Sucre, Bolivia, 2008; pp. 163-200.

33. Salazar, D.; Salinas, H.; McRostie, V.; Labarca, R.; Vega, G. Cerro Turquesa: Diez siglos de producción minera en el extremo norte de Chile. In Proceedings of the Actas Del XVII Congreso Nacional de Arqueología Chilena, Valdivia, Chile, 9 October 2006; Ediciones Kultrún: Valdivia, Chile, 2010; Volume 2, pp. 1085-1097.

34. Salazar, D.; Borie, C.; Oñate, C. Mining, Commensal Politics, and Ritual under Inca Rule in Atacama, Northern Chile. In Mining and Quarrying in the Ancient Andes: Sociopolitical, Economic, and Symbolic Dimensions; Tripcevich, N., Vaughn, K., Eds.; Springer: New York, NY, USA, 2013; pp. 253-274. [CrossRef] 
35. Aldunate, C.; Castro, V.; Varela, V. San Bartolo. Retazos de una historia de la minería en Atacama. In Proceedings of the Actas Del XVI Congreso Nacional de Arqueología Chilena, Concepción, Chile, 13-17 October 2003; Ediciones Escaparate: Concepción, Chile, 2005; pp. 213-224.

36. Aldunate, C.; Castro, V.; Varela, V. San Bartolo y Cobija: Testimonios de un modo de vida minero en las tierras altas y la costa de Atacama. Estud Atacameños 2008, 35, 97-118. [CrossRef]

37. Westfall, C.; González, C. Mina Las Turquesas: Un asentamiento minero lapidario preincaico en el extremo meridional circumpuneño, Región de Atacama, Chile. In Proceedings of the Actas Del XVII Congreso Nacional de Arqueología Chilena; Valdivia, Chile, 9 October 2006, Ediciones Kultrún: Valdivia, Chile, 2010; Volume 2, pp. 1073-1084.

38. Cantarutti, G.E. Mining Under Inca Rule in North-Central Chile: The Los Infieles Mining Complex. In Mining and Quarrying in the Ancient Andes; Springer: New York, NY, USA, 2013; pp. 185-211. [CrossRef]

39. Bourgarit, D.; Mille, B. Provenance du cuivre et al.liages. In Circulation et Provenance Des. Matériaux Dans Les Sociétés Anciennes; Dillmann, P., Bellot-Gurlet, L., Eds.; Éditions des Archives Contemporaines: Paris, France, 2014; pp. 103-132. [CrossRef]

40. Chavez, W. Supergene oxidation of copper deposits: Zoning and distribution of copper oxide minerals. Soc. Econ. Geol. Newsl. 2000, 41, 1-21. [CrossRef]

41. Thibodeau, A.M. Isotopic Evidence For The Provenance of Turquoise, Mineral Paints, And Metals in the Southwestern United States. Ph.D. Thesis, University of Arizona, Tucson, AZ, USA, 2012.

42. Kim, J.; Simon, A.W.; Ripoche, V.; Mayer, J.W.; Wilkens, B. Proton-induced x-ray emission analysis of turquoise artefacts from Salado platform Mound sites in the Tonto Basin of central Arizona. Meas Sci Technol. 2003, 14, 1579-1589. [CrossRef]

43. González, C.; Westfall, C.; Castells, C. Mina las turquesas: Lapidaria, secuencia alfarera prehispánica e interrelaciones culturales en un espacio internodal del Desierto de Atacama, Chile. Estud Atacameños 2017, 56, 225-251. [CrossRef]

44. Van Hoesen, J.; Arriaza, B.; Ryan, P.; Grady, C. A multianalytical approach for identifying a manganese source for the black pigment of the Chinchorro mortuary palette. Geoarchaeology 2019, 34, 322-335. [CrossRef]

45. Carrión, H. Producción e identidad: Cuentas de Mineral de Cobre durante el Periodo Medio en San Pedro de Atacama. Tesis para optar al Título de Arqueólogo, Universidad de Chile, Santiago, Chile, 2015.

46. Figueroa, V.; Salazar, D.; Mille, B.; Manríquez, G. Metal Use and Production among Coastal Societies of the Atacama Desert. Archaeometry 2015, 57, 687-703. [CrossRef]

47. Coquinot, Y.; (Centre de Recherche et de Restauration des Musées de France, Paris, France). Field Observations and Results of Sample Analysis of Two Secondary Copper Mineral Deposits from: 1) the El Abra Turquoise-Rich Deposit and 2) Cerro Verde, Caspana "Chrysocolla-Azurite-Malachite-Cryptomelane", Deposit. Report on File. Proyecto Arqueológico El Abra, 2013. Unpublished work.

48. Sepúlveda, M.; Figueroa, V.; Pagés-Camagna, S. Copper Pigment-Making in the Atacama Desert (Northern Chile). Lat. Am. Antiq. 2013, 24, 467-482.

49. Sepúlveda, M.; Valenzuela, D.; Cornejo, L.; Lienqueo, H.; Rousselière, H. Óxidos de manganeso en el extremo norte de Chile: Abastecimiento, producción y movilidad del color negro durante el Período Arcaico. Chungará 2013, 45, 143-159. [CrossRef]

50. Aldunate, C. El pukara de Turi: Un testimonio monumental de continuidad cultural en la subárea Circumpuneña (s. XI al XVII). In Actas Del XII Congreso Nacional de Arqueología Chilena; Museo Regional de la Araucanía: Temuco, Chile, 1991; Volume 2, pp. 61-78.

51. Scheller, S.; Tagle, R.; Gloy, G.; Barraza, M.; Menzies, A. Advancements in Minerals Identification and Characterization in Geo-Metallurgy: Comparing E-Beam and Micro-X-ray-Fluorescence Technologies. Microsc Microanal. 2017, 23, $2168-2169$. [CrossRef]

52. Garrison, E. X-Ray diffraction (XRD): Applications in Archaeology. In Encyclopedia of Global Archaeology; Smith, C., Ed.; Springer: New York, NY, USA, 2014; pp. 7929-7933.

53. Inizan, M.-L.; Reduron-Ballinger, M.; Roche, H.; Tixier, J. Technology and Terminology of Knapped Stone; CREP: Nanterre, France, 1999.

54. Pelegrin, J. Les techniques de débitage laminaire au Tardiglaciaire: Critères de diagnose et quelques réflexions. Mémoires du Musée préhistoire d'Ile-de-France 2000, 7, 73-86.

55. Pelegrin, J. Remarks about archaeological techniques and methods of knapping: Elements of a cognitive approach to stone knapping. In Stone Knapping: The Necessary Conditions for a Uniquely Hominin Behaviour; McDonald Institute for Archaeological Research: Cambridge, UK; pp. 23-33.

56. Núñez, L.; Agüero, C.; Cases, B.; de Souza, P. El campamento minero Chuquicamata-2 y la explotación cuprífera prehispánica en el Desierto de Atacama. Estud Atacameños 2003, 25, 7-34. [CrossRef]

57. Faivre, J.-P.; Geneste, J.-M.; Turq, A. La fracturation en split, une technique de production dans l'industrie lithique des Tares (Sourzac, Dordogne). Paléo 2010, 133-142. [CrossRef]

58. Kahou, Z.S.; Duchêne, S.; Brichau, S.; Campos, E.; Estrade, G.; Poujol, M.; Kathirgamar, J.; Testa, H.; Leisen, M.; Choy, S.; et al. Mineralogical and chemical characterization of supergene copper-bearing minerals: Examples from Chile and Burkina Faso. Ore Geol. Rev. 2021, 133, 104078. [CrossRef]

59. Camus, F. Geología de Los Sistemas Porfíricos En Los Andes de Chile; Servicio Nacional de Geología y Minería: Santiago, Chile, 2003; p. 267.

60. Cuadra, C.P.; Rojas, S.G. Oxide mineralization at the Radomiro Tomic porphyry copper deposit, Northern Chile. Econ. Geol. 2001, 96, 387-400. [CrossRef] 
61. Cuadra, P.; Camus, F.; Porter, T.M. The Radomiro Tomic Porphyry Copper Deposit, Northern Chile. In Porphyry and Hydrothermal Copper and Gold Deposits: A Global Perspective; PGC Publishing: Adelaide, Australia, 1998; pp. 99-110.

62. Reich, M.; Palacios, C.; Vargas, G.; Luo, S.; Cameron, E.M.; Leybourne, M.I.; Parada, M.A.; Zúñiga, A.; You, C.F. Supergene enrichment of copper deposits since the onset of modern hyperaridity in the Atacama Desert, Chile. Miner. Depos. 2009, 44, 497-504. [CrossRef]

63. Cameron, E.M.; Leybourne, M.I.; Palacios, C. Atacamite in the oxide zone of copper deposits in northern Chile: Involvement of deep formation waters? Miner. Depos. 2007, 42, 205-218. [CrossRef]

64. Adán Alfaro, L. Aquellos antiguos edificios. Acercamiento arqueológico a la arquitectura prehispánica tardía de Caspana. Estud Atacameños 1999, 18, 13-34. [CrossRef]

65. Salazar, D.; Berenguer, J.; Vega, G. Paisajes minero-metalúrgicos incaicos en Atacama y el Altiplano Sur de Tarapacá (norte de Chile). Chungará 2013, 45, 83-103. [CrossRef]

66. Bovisio, M.A. Acerca de la naturaleza de la noción de wak'a: Objetos y conceptos. In Wak'as, Diablos y Muertos: Alteridades Significantes En El Mundo Andino; Bugallo, L., Vilca, M., Eds.; Universidad Nacional de Jujuy \& Instituto Francés de Estudios Andinos: Jujuy, Argentina; Lima, Perú, 2016; pp. 73-110.

67. van Kessel, J. Ritual de Producción y Discurso Tecnológico. Chungara 1989, 23, 73-91.

68. Drennan, R. Statistics for Archaeologists: A Common Sense Approach, 2nd ed.; Springer: Dordrecht, The Netherlands; Heidelberg, Germany, 2009. [CrossRef] 